\title{
LEVEL II SCOUR ANALYSIS FOR BRIDGE 29 (READTH00510029) on TOWN HIGHWAY 51, crossing MILL BROOK, READING, VERMONT
}

Open-File Report 98-402

Prepared in cooperation with

VERMONT AGENCY OF TRANSPORTATION

and

FEDERAL HIGHWAY ADMINISTRATION

U.S. Department of the Interior

U.S. Geological Survey

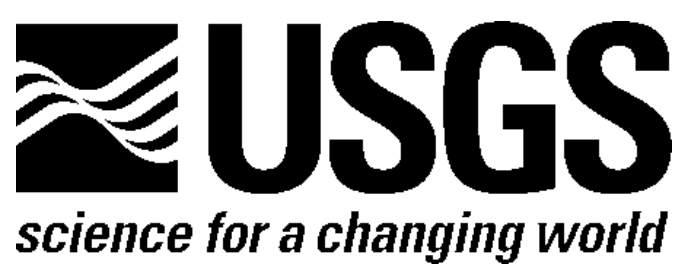




\section{LEVEL II SCOUR ANALYSIS FOR BRIDGE 29 (READTH00510029) on TOWN HIGHWAY 51, crossing MILL BROOK, READING, VERMONT}

By RONDA L. BURNS and MATTHEW A. WEBER

U.S. Geological Survey Open-File Report 98-402

Prepared in cooperation with

VERMONT AGENCY OF TRANSPORTATION

and

FEDERAL HIGHWAY ADMINISTRATION 


\title{
U.S. DEPARTMENT OF THE INTERIOR BRUCE BABBITT, Secretary
}

\author{
U.S. GEOLOGICAL SURVEY
}

Thomas J. Casadevall, Acting Director

For additional information write to:

District Chief

U.S. Geological Survey 361 Commerce Way

Pembroke, NH 03275-3718
Copies of this report may be purchased from:

U.S. Geological Survey

Branch of Information Services

Open-File Reports Unit

Box 25286

Denver, CO 80225-0286 


\section{CONTENTS}

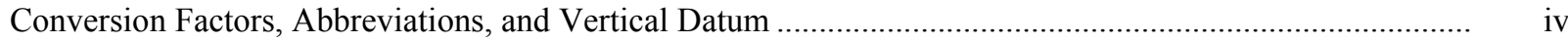

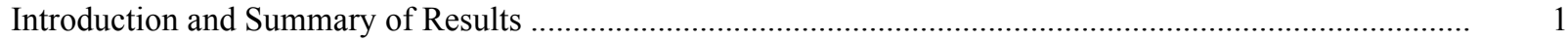

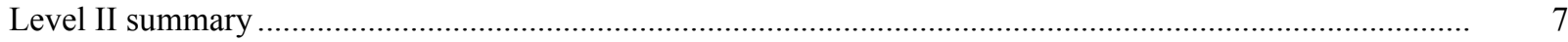

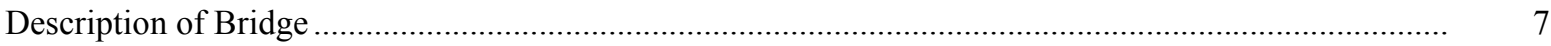

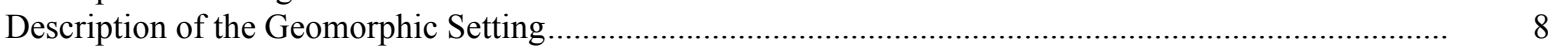

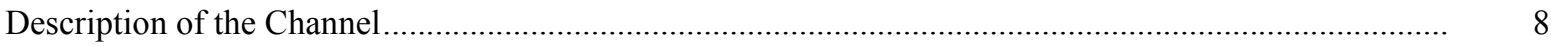

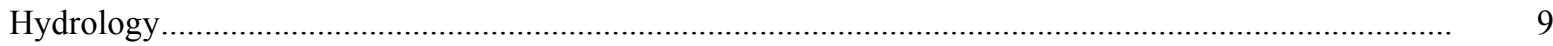

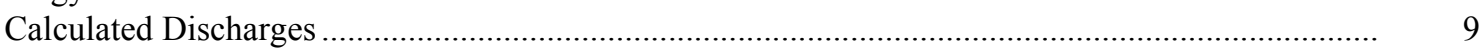

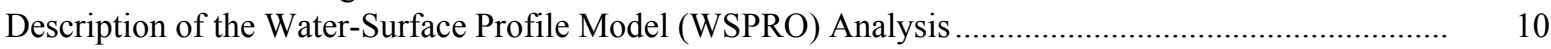

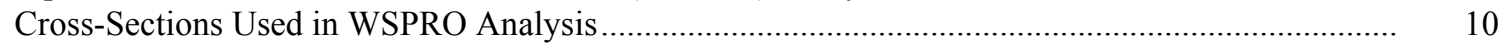

Data and Assumptions Used in WSPRO Model ........................................................................ 11

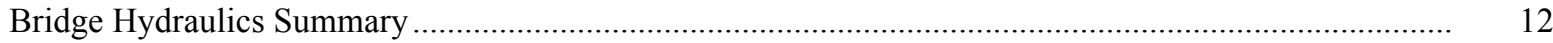

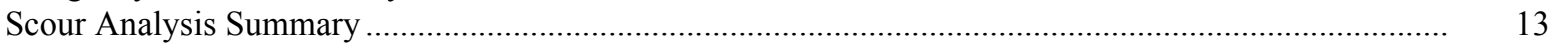

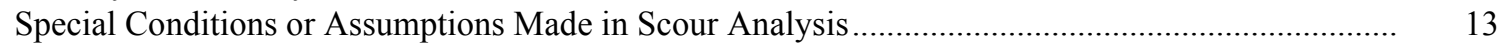

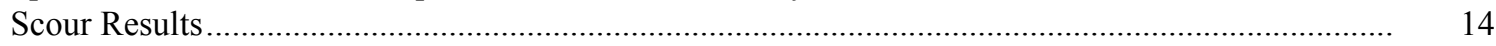

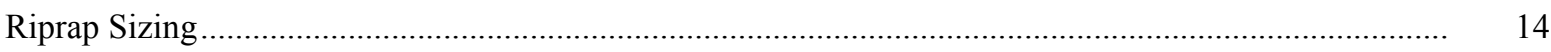

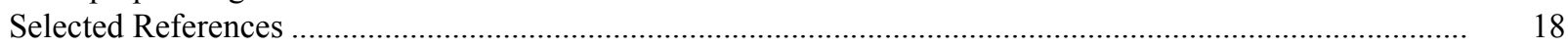

Appendices:

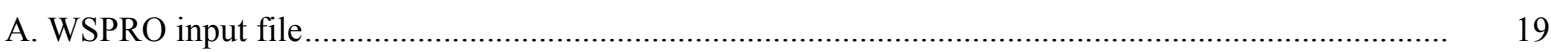

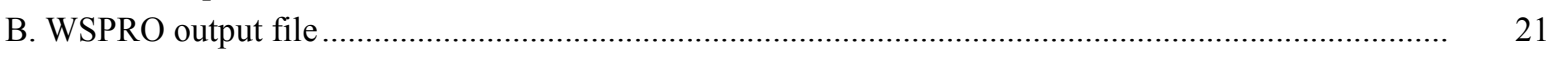

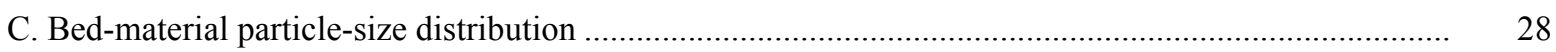

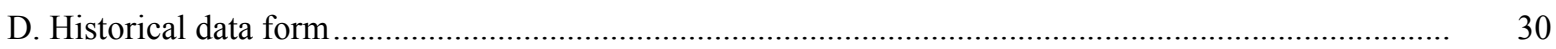

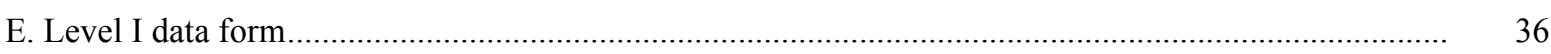

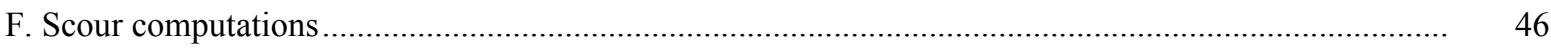

\section{FIGURES}

1. Map showing location of study area on USGS 1:24,000 scale map

2. Map showing location of study area on Vermont Agency of Transportation town highway map

3. Structure READTH00510029 viewed from upstream (March 29, 1995).

4. Downstream channel viewed from structure READTH00510029 (March 29, 1995)

5. Upstream channel viewed from structure READTH00510029 (March 29, 1995)

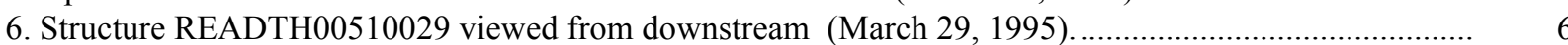

7. Water-surface profiles for the 100- and 500-year discharges at structure

READTH00510029 on Town Highway 51, crossing Mill Brook,

Reading, Vermont.

8. Scour elevations for the 100- and 500-year discharges at structure

READTH00510029 on Town Highway 51, crossing Mill Brook,

Reading, Vermont.

\section{TABLES}

1. Remaining footing/pile depth at abutments for the 100-year discharge at structure

READTH00510029 on Town Highway 51, crossing Mill Brook,

Reading, Vermont

2. Remaining footing/pile depth at abutments for the 500-year discharge at structure

READTH00510029 on Town Highway 51, crossing Mill Brook,

Reading, Vermont. 


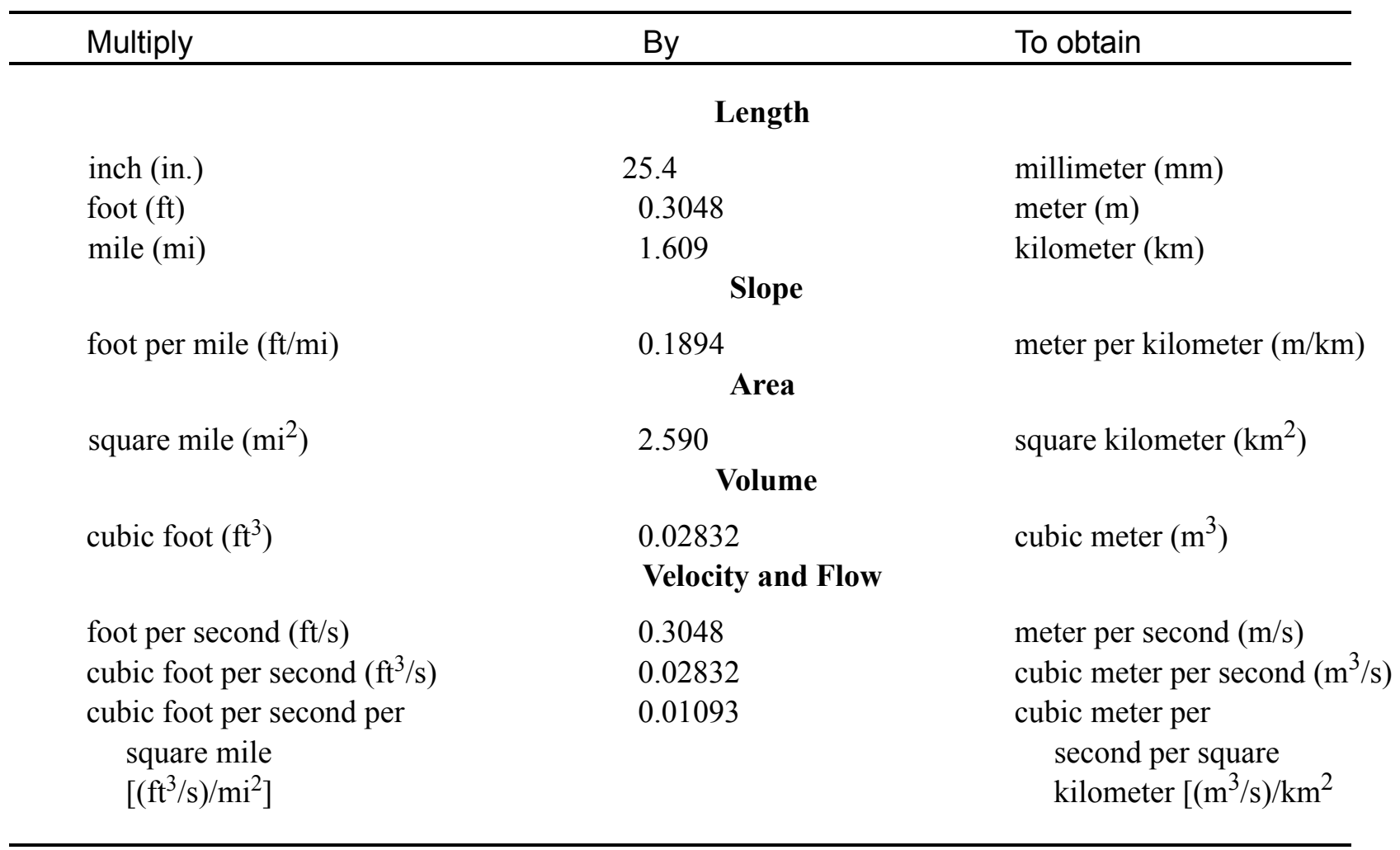

\section{OTHER ABBREVIATIONS}

$\begin{array}{lrlr}\mathrm{BF} & \text { bank full } & \text { LWW } & \text { left wingwall } \\ \mathrm{cfs} & \text { cubic feet per second } & \text { Max } & \text { maximum } \\ \mathrm{D}_{50} & \text { median diameter of bed material } & \text { MC } & \text { main channel } \\ \mathrm{DS} & \text { downstream } & \text { RAB } & \text { right abutment } \\ \mathrm{elev} & \text { elevation } & \text { RABUT } & \text { face of right abutment } \\ \mathrm{f} / \mathrm{p} & \text { flood plain } & \text { RB } & \text { right bank } \\ \mathrm{ft} & \text { square feet } & \text { ROB } & \text { right overbank } \\ \mathrm{ft} / \mathrm{ft} & \text { feet per foot } & \text { RWW } & \text { right wingwall } \\ \mathrm{FEMA} & \text { Federal Emergency Management Agency } & \text { TH } & \text { town highway } \\ \mathrm{FHWA} & \text { Federal Highway Administration } & \text { UB } & \text { under bridge } \\ \mathrm{JCT} & \text { junction } & \text { US } & \text { upstream } \\ \text { LAB } & \text { left abutment } & \text { USGS } & \text { United States Geological Survey } \\ \text { LABUT } & \text { face of left abutment } & \text { VTAOT } & \text { Vermont Agency of Transportation } \\ \text { LB } & \text { left bank } & \text { WSPRO } & \text { water-surface profile model } \\ \text { LOB } & \text { left overbank } & \text { yr } & \text { year }\end{array}$

In this report, the words "right" and "left" refer to directions that would be reported by an observer facing downstream. Sea level: In this report, "sea level" refers to the National Geodetic Vertical Datum of 1929-- a geodetic datum derived from a general adjustment of the first-order level nets of the United States and Canada, formerly called Sea Level Datum of 1929.

In the appendices, the above abbreviations may be combined. For example, USLB would represent upstream left bank. 


\title{
LEVEL II SCOUR ANALYSIS FOR BRIDGE 29 (READTH00510029) ON TOWN HIGHWAY 51, CROSSING MILL BROOK, READING, VERMONT
}

\author{
By Ronda L. Burns and Matthew A. Weber
}

\section{INTRODUCTION AND SUMMARY OF RESULTS}

This report provides the results of a detailed Level II analysis of scour potential at structure READTH00510029 on Town Highway 51 crossing Mill Brook, Reading, Vermont (figures 1-8). A Level II study is a basic engineering analysis of the site, including a quantitative analysis of stream stability and scour (FHWA, 1993). Results of a Level I scour investigation also are included in appendix $\mathrm{E}$ of this report. A Level I investigation provides a qualitative geomorphic characterization of the study site. Information on the culvert, gleaned from Vermont Agency of Transportation (VTAOT) files, was compiled prior to conducting Level I and Level II analyses and is found in appendix D.

The site is in the New England Upland section of the New England physiographic province in eastern Vermont. The $9.56-\mathrm{mi}^{2}$ drainage area is in a predominantly rural and forested basin. In the vicinity of the study site, the surface cover is pasture upstream of the culvert and on the left bank downstream, while the immediate banks are tree or shrub covered. The downstream right bank is forested.

In the study area, Mill Brook has a sinuous channel with a slope of approximately $0.008 \mathrm{ft} /$ $\mathrm{ft}$, an average channel top width of $45 \mathrm{ft}$ and an average bank height of $3 \mathrm{ft}$. The channel bed material is mainly gravel with a median grain size $\left(\mathrm{D}_{50}\right)$ of $77.5 \mathrm{~mm}(0.254 \mathrm{ft})$. The geomorphic assessment at the time of the Level I site visit on March 29, 1995 and Level II site visit on July 29, 1996, indicated that the reach was laterally unstable. There are cutbanks upstream and downstream of the culvert and heavy fluvial erosion on the downstream banks.

The Town Highway 51 crossing of Mill Brook is a 27-ft-long, one-lane structure consisting of a 25-foot span, steel, multi-plate arch culvert (Vermont Agency of Transportation, written communication, March 8, 1995). The opening length of the structure parallel to the culvert face is $24.7 \mathrm{ft}$. The channel is skewed approximately 30 degrees to the opening while the computed opening-skew-to-roadway is 20 degrees. 
A scour hole $3.0 \mathrm{ft}$ deeper than the mean thalweg depth was observed along the upstream end of the left side of the culvert during the Level I assessment. The only scour protection measure at the site was type-2 stone fill (less than 36 inches diameter) at the upstream and downstream corners of the culvert along the embankment. Additional details describing conditions at the site are included in the Level II Summary and appendices D and E.

Scour depths and recommended rock rip-rap sizes were computed using the general guidelines described in Hydraulic Engineering Circular 18 (Richardson and Davis, 1995) for the 100- and 500-year discharges. In addition, the incipient roadway-overtopping discharge was determined and analyzed as another potential worst-case scour scenario. Total scour at a highway crossing is comprised of three components: 1) long-term streambed degradation; 2) contraction scour (due to accelerated flow caused by a reduction in flow area at a bridge) and; 3) local scour (caused by accelerated flow around piers and abutments). Total scour is the sum of the three components. Equations are available to compute depths for contraction and local scour and a summary of the results of these computations follows.

Contraction scour for all modelled flows ranged from 0.0 to $0.5 \mathrm{ft}$. The worst-case contraction scour occurred at the incipient roadway-overtopping discharge, which was less than the 100-year discharge. Left abutment scour ranged from 5.3 to $11.3 \mathrm{ft}$. Right abutment scour ranged from 12.9 to $19.2 \mathrm{ft}$. The worst-case abutment scour occurred at the 500-year discharge. Additional information on scour depths and depths to armoring are included in the section titled "Scour Results". Scoured-streambed elevations, based on the calculated scour depths, are presented in tables 1 and 2. A cross-section of the scour computed at the culvert is presented in figure 8. Scour depths were calculated assuming an infinite depth of erosive material and a homogeneous particle-size distribution.

It is generally accepted that the Froehlich equation (abutment scour) gives "excessively conservative estimates of scour depths" (Richardson and Davis, 1995, p. 46). Usually, computed scour depths are evaluated in combination with other information including (but not limited to) historical performance during flood events, the geomorphic stability assessment, existing scour protection measures, and the results of the hydraulic analyses. Therefore, scour depths adopted by VTAOT may differ from the computed values documented herein. 


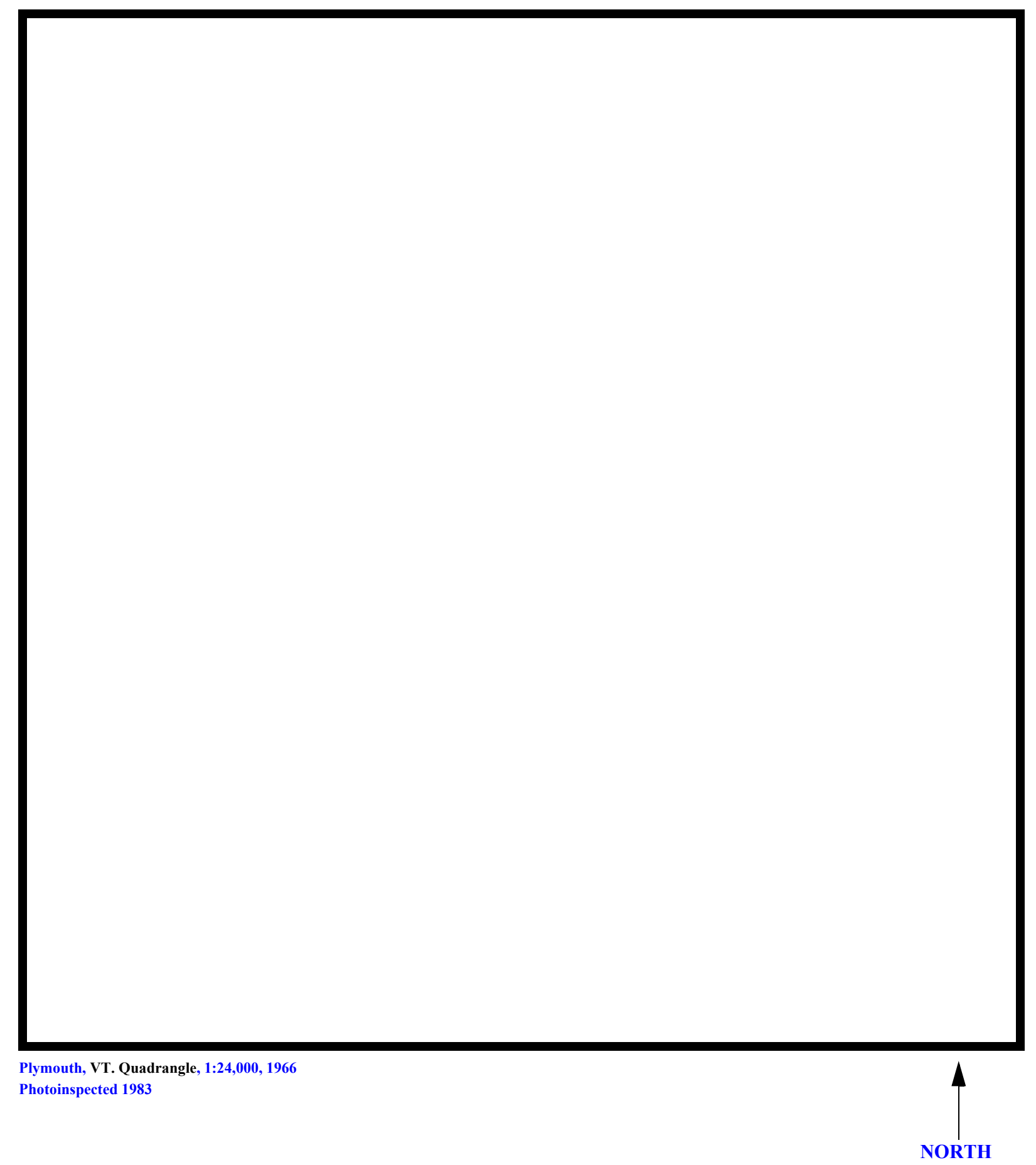

Figure 1. Location of study area on USGS 1:24,000 scale map. 
Figure 2. Location of study area on Vermont Agency of Transportation town highway map. 

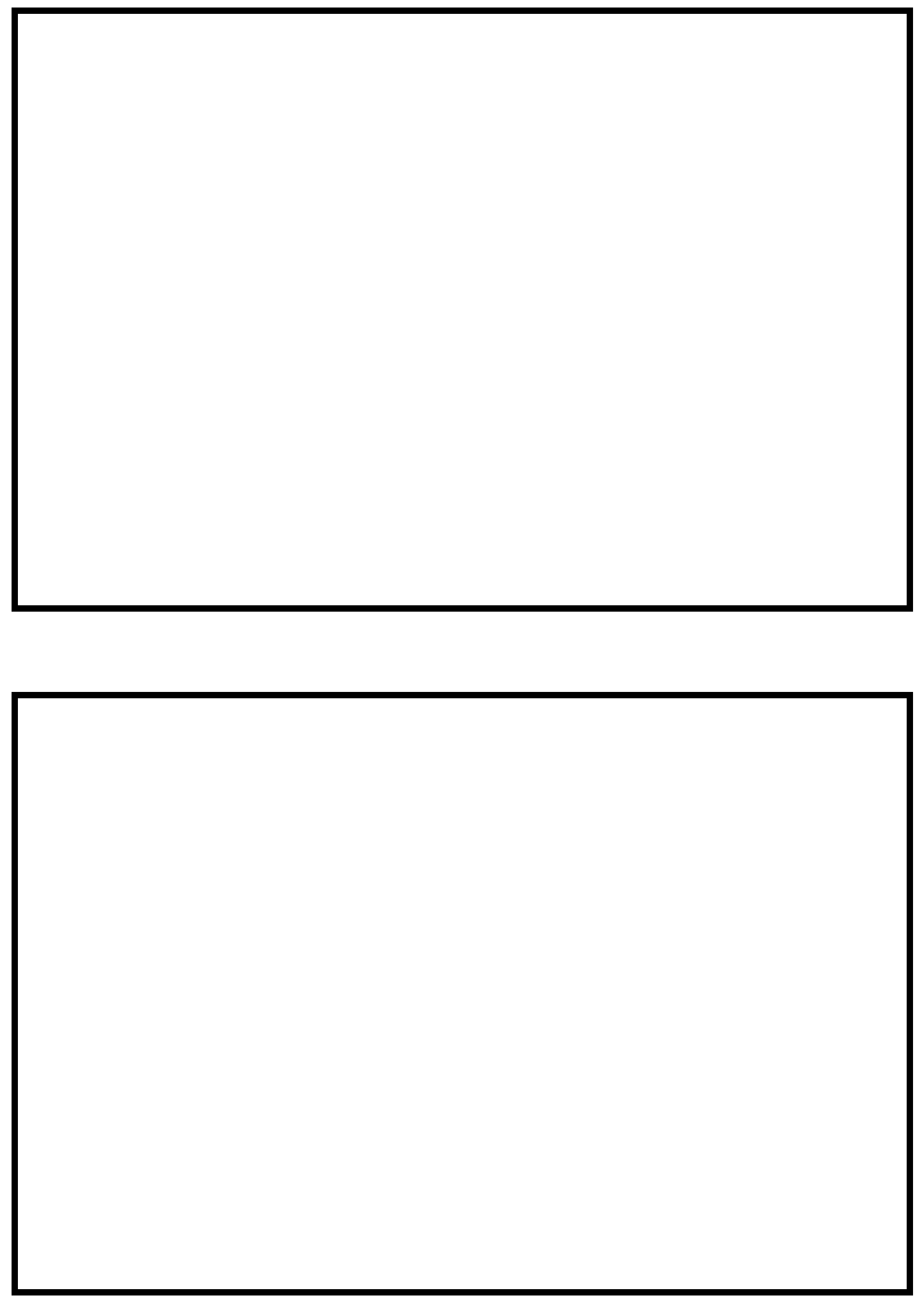

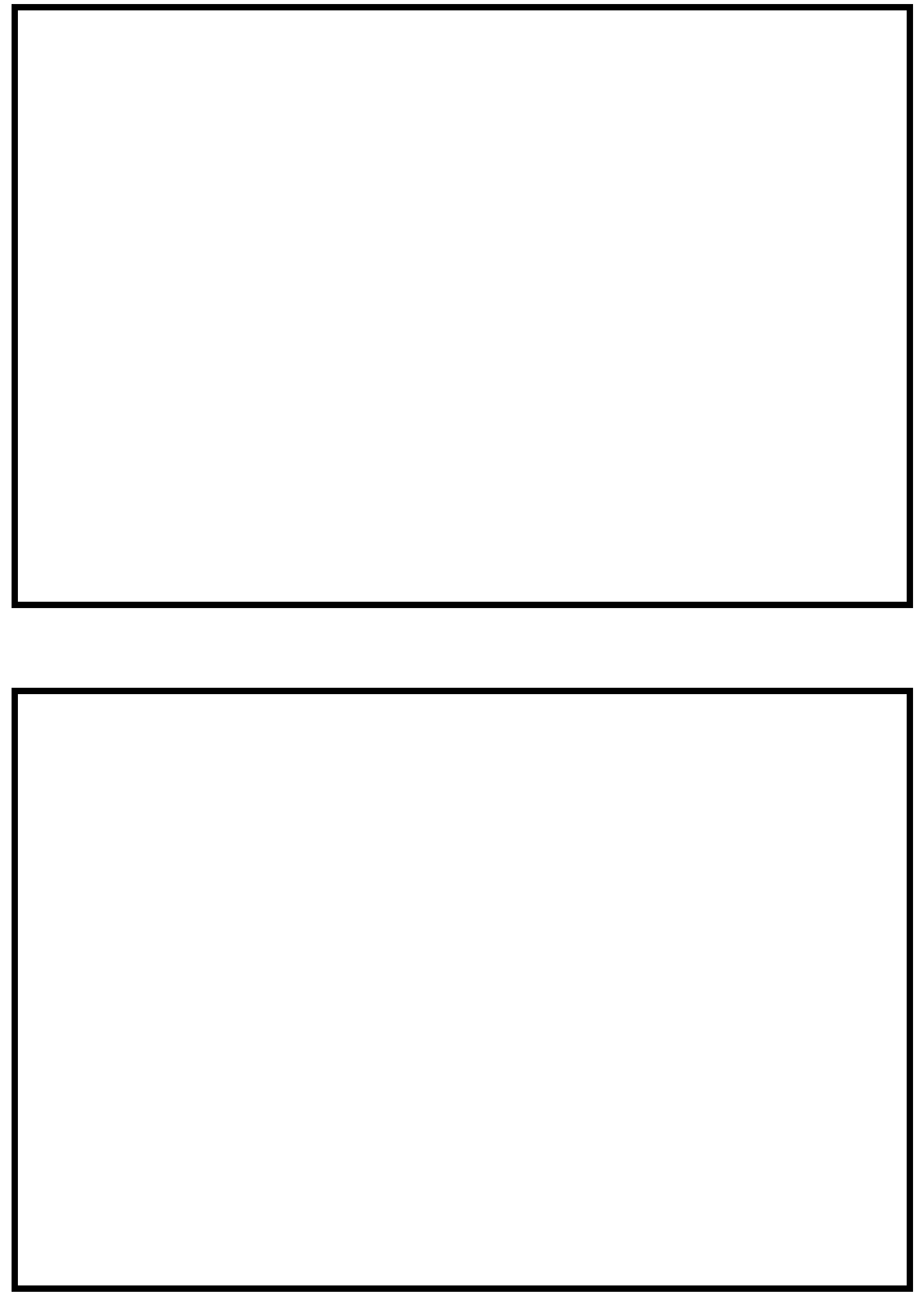


\section{LEVEL II SUMMARY}

\begin{tabular}{|c|c|c|c|}
\hline Structure Number & READTH00510029 & Stream & Mill \\
\hline Win & & & TH 51 \\
\hline
\end{tabular}

\section{Description of Bridge}

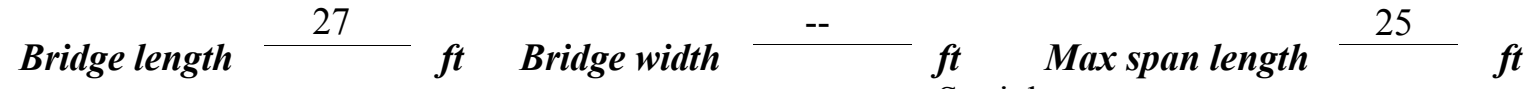
Alignment of bridge to road (on curve or straight)

\section{Abutment type} N/A

Stone fill on abutment? No

\section{Embankment type}

noto of incnortion Straight
Sloping $3 / 29 / 95$ Damanimtine. af ata.. a fill Type-2, at the upstream and downstream ends of the culvert on the embankment.

The culvert is a multi-plate corrugated steel pipe arch with concrete footings. There is a $3 \mathrm{ft}$ deep scour hole along the upstream left side of the culvert. Yes

$$
30
$$
Yes

Is bridge skewed to flood flow according to There ' survey? Angle is a moderate channel bend in the upstream reach. The sçour hole has developed in the location where the flow impacts the upstream left side of the culvert.

Debris accumulation on bridge at time of Level I or Level II site visit:

$$
\begin{gathered}
\text { Date af insnortion } \\
3 / 29 / 95 \\
\hline
\end{gathered}
$$

Level I

$$
7 / 29 / 96
$$

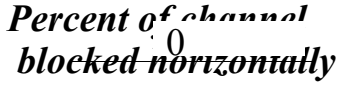

0

\section{Percent of an n....el blocked verticatty}

0

Level II

Moderate. Some debris was caught at the upstream face of the culvert on 3/29/95.

Potential for debris

None as of 7/29/96.

Doscriho any, foaturos noar ar at tho hridos that mav, affoct flou, (includo ahsorvation dato) 


\section{Description of the Geomorphic Setting}

General topography The channel is located in a high relief valley with a wide flood plain on the left.

Geomorphic conditions at bridge site: downstream (DS), upstream (US)

Date of inspection $\quad 3 / 29 / 95$

DS left: $\quad$ Steep channel bank to a wide flood plain and the VT 106 roadway

DS right: $\quad$ Steep valley wall

US left: $\quad$ Steep channel bank to a wide flood plain and the VT 106 roadway

US right: $\quad$ Moderately sloping channel bank to a steep valley wall

\section{Description of the Channel}

\begin{tabular}{|c|c|c|c|}
\hline \multirow[b]{2}{*}{ Average top width } & 45 & \multirow[b]{2}{*}{ Average depth } & \multirow[b]{2}{*}{ Silt/Sand/Gravel } \\
\hline & $\stackrel{\boldsymbol{f t}}{\text { Sand/Gravel }}$ & & \\
\hline Predominant bed & & Bank material & Sinuous with semi- \\
\hline
\end{tabular}

alluvial channel boundaries and irregular point and lateral bars.

$3 / 29 / 95$

Vegetative co 1 Trees and brush with grass on the flood plain

DS left: $\quad$ Trees and brush

DS right: $\quad$ Shrubs and brush with grass on the flood plain

US left: $\quad$ Shrubs and brush with grass on the overbank

US right: $\quad$ No

Do banks appear stable? Cut-banks were observed upstream and downstream of the culvert on $3 / 29 / 95$. There is heavy fluvial erosion with mass wasting on the banks downstream of the
date of observatton. culvert.

across the channel in the downstream reach as of 3/29/95 and 7/29/96. Describe any obstructions in channel and date of observation. 


\title{
Hydrology
}

Drainage area $\stackrel{9.56}{\mathrm{mi}^{2}}$

Percentage of drainage area in physiographic provinces: (approximate)

Physiographic province/section New England/New England Upland
Percent of drainage area 100

\begin{abstract}
Is drainage area considered rural or urban?
Rural None

urbanization:

Describe any significant
\end{abstract}

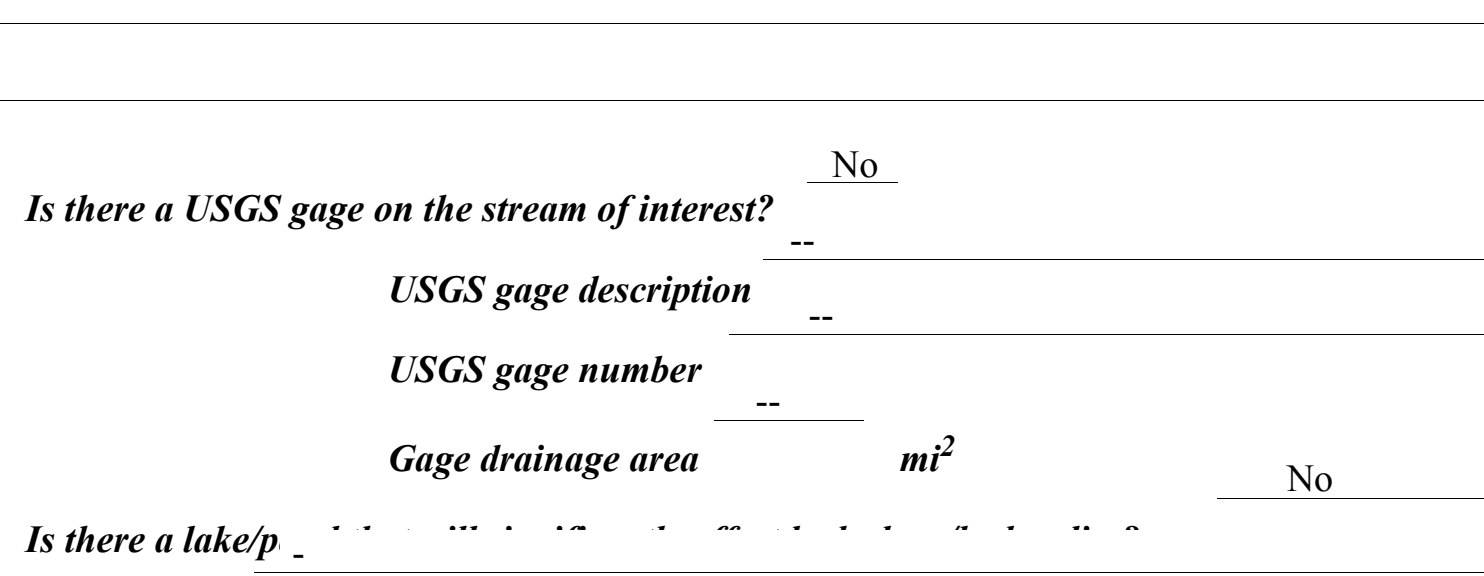

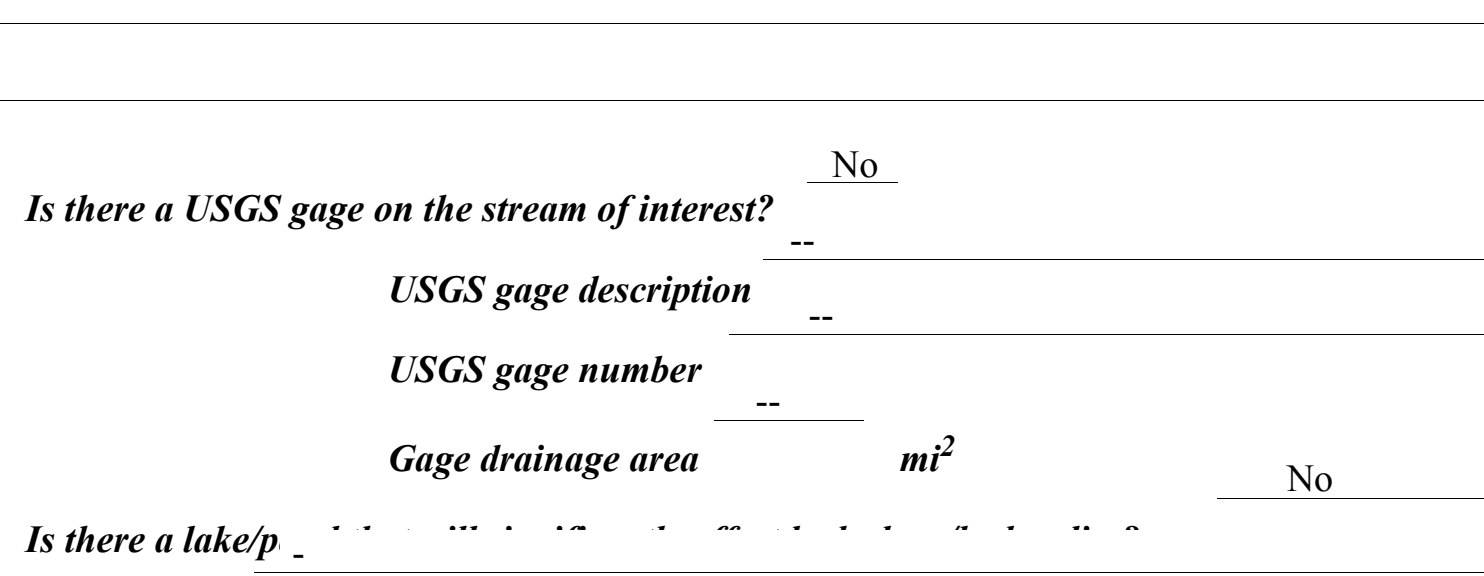

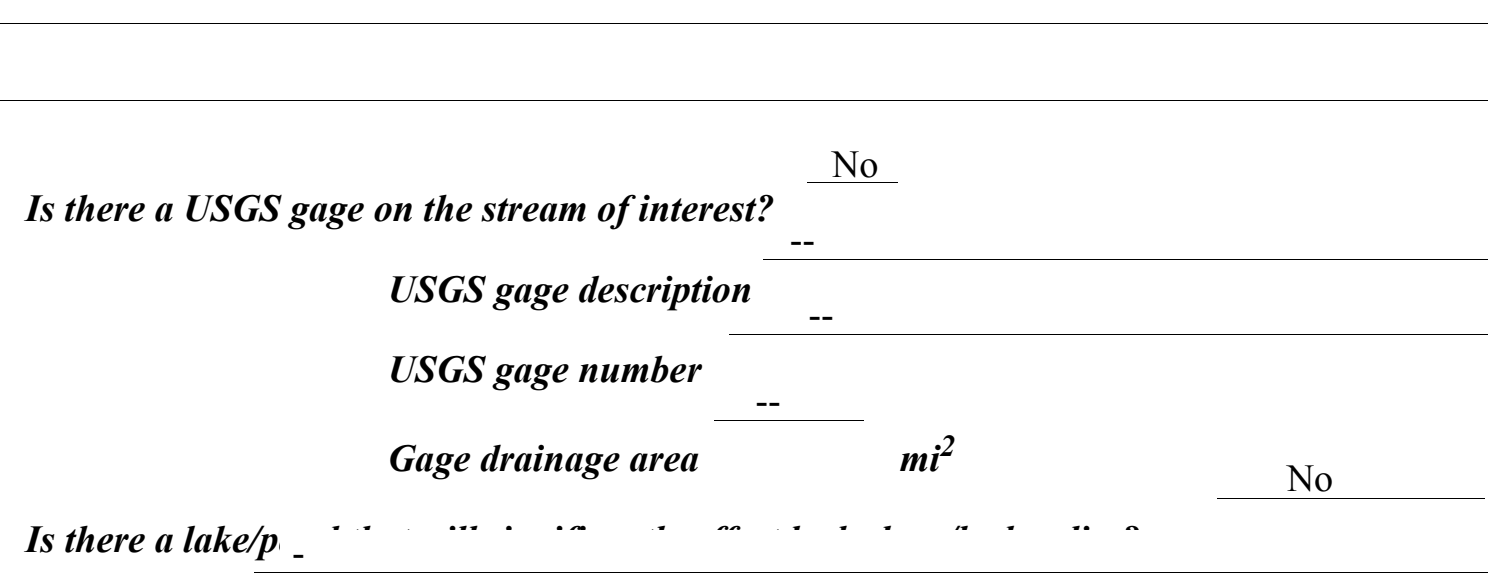

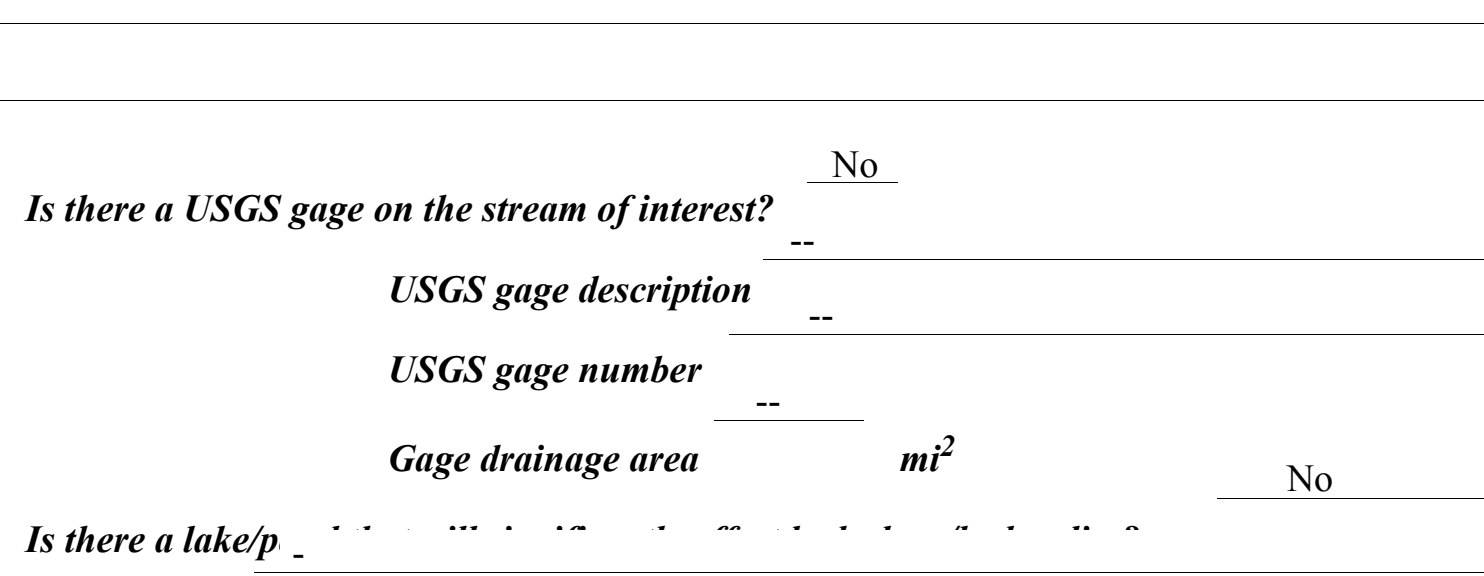

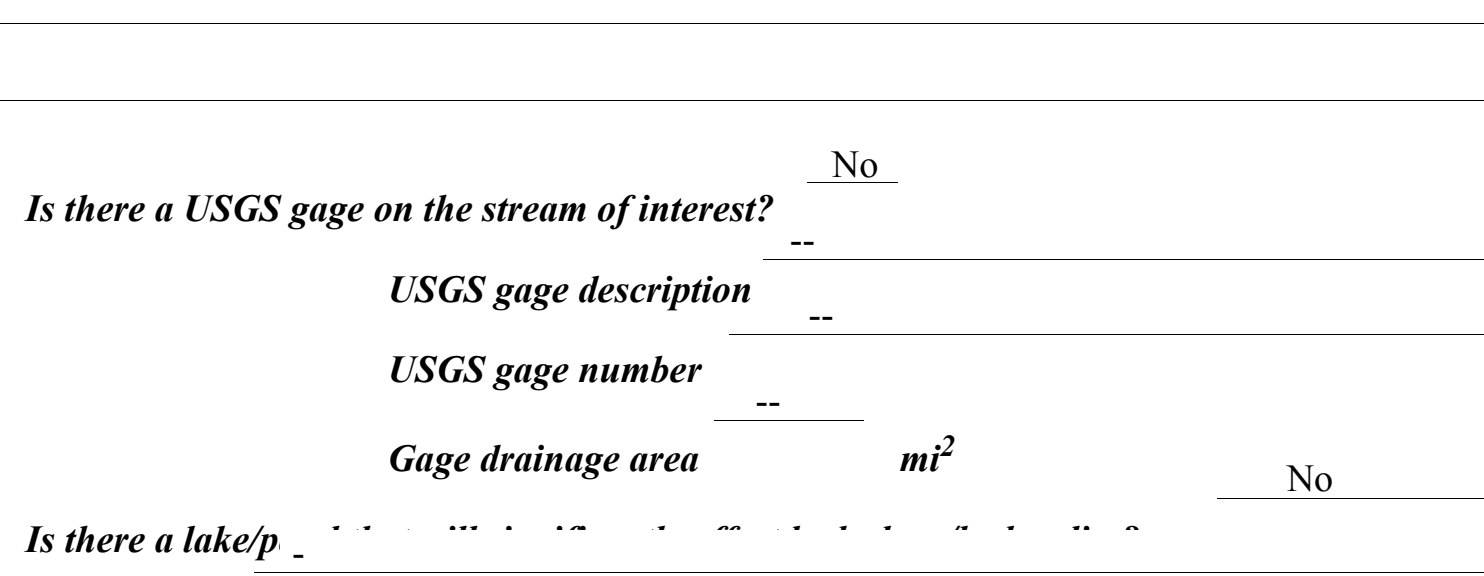

Is there a lake/p

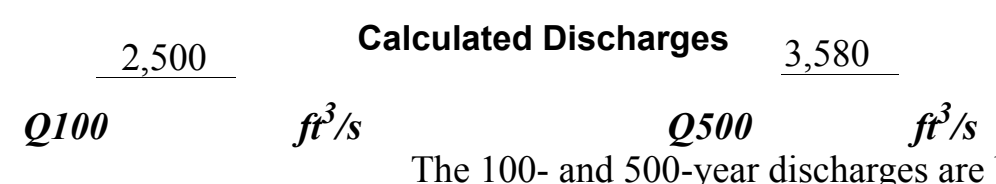

frequency estimates available from the VTAOT database (written communication, May 1995) for bridge number 25 in Reading. Bridge number 25 crosses Mill Brook upstream of this site and has a drainage area of 9.54 square miles. These values were within a range defined by flood frequency curves derived from several empirical methods (Benson, 1962; Johnson and Tasker, 1974; FHWA, 1983; Potter, 1957a\&b; Talbot, 1887). Each curve was extended graphically to the 500-year event. 


\section{Description of the Water-Surface Profile Model (WSPRO) Analysis}

Datum for WSPRO analysis (USGS survey, sea level, VTAOT plans)

USGS survey

Datum tie between USGS survey and VTAOT plans

Subtract $8.8 \mathrm{ft}$ from the USGS

arbitrary survey datum to obtain the VTAOT plans' datum.

Description of reference marks used to determine USGS datum. $\quad$ RM1 is a nail in

telephone pole \#170-1 on the downstream left bank, $50 \mathrm{ft}$ from the culvert (elev. $494.65 \mathrm{ft}$,

arbitrary survey datum). RM2 is a bolt on top of the culvert at the downstream end near the

center (elev. $492.78 \mathrm{ft}$, arbitrary survey datum). RM3 is a bolt on top of the culvert at the

upstream end to the left of center (elev. $493.27 \mathrm{ft}$, arbitrary survey datum).

\section{Cross-Sections Used in WSPRO Analysis}

\begin{tabular}{cccl}
\hline${ }^{1}$ Cross-section & $\begin{array}{c}\text { Section } \\
\text { Reference } \\
\text { Distance } \\
\text { (SRD) } \text { in feet }\end{array}$ & $\begin{array}{c}{ }^{2} \text { Cross-section } \\
\text { development }\end{array}$ & \multicolumn{1}{c}{ Comments } \\
\hline EXITX & -22 & 1 & $\begin{array}{l}\text { Exit section } \\
\text { Downstream Full-valley } \\
\text { section (Templated from } \\
\text { EXITX) }\end{array}$ \\
FULLV & 0 & 2 & $\begin{array}{l}\text { Culvert section } \\
\text { RRIDG }\end{array}$ \\
RDWAY & 0 & 1 & $\begin{array}{l}\text { Road Grade section } \\
\text { Modelled Approach sec- } \\
\text { tion (Templated from } \\
\text { APTEM) } \\
\text { APPRO }\end{array}$ \\
& 67 & 1 & $\begin{array}{l}\text { Approach section as sur- } \\
\text { veyed (Used as a tem- } \\
\text { plate) }\end{array}$ \\
\hline
\end{tabular}

${ }^{1}$ For location of cross-sections see plan-view sketch included with Level I field form, Appendix E. For more detail on how cross-sections were developed see WSPRO input file. 


\section{Data and Assumptions Used in WSPRO Model}

Hydraulic analyses of the reach were done by use of the Federal Highway Administration's WSPRO step-backwater computer program (Shearman and others, 1986, and Shearman, 1990). The analyses reported herein reflect conditions existing at the site at the time of the study. Furthermore, in the development of the model it was necessary to assume no accumulation of debris or ice at the site. Results of the hydraulic model are presented in the Bridge Hydraulic Summary, appendix B, and figure 7.

Channel roughness factors (Manning's " $n$ ") used in the hydraulic model were estimated using field inspections at each cross section following the general guidelines described by Arcement and Schneider (1989). Final adjustments to the values were made during the modelling of the reach. Channel " $\mathrm{n}$ " values for the reach ranged from 0.040 to 0.060 , and overbank " $\mathrm{n}$ " values ranged from 0.041 to 0.050 .

Normal depth at the exit section (EXITX) was assumed as the starting water surface. This depth was computed by use of the slope-conveyance method outlined in the user's manual for WSPRO (Shearman, 1990). The slope used was $0.0083 \mathrm{ft} / \mathrm{ft}$, which was estimated from thalweg points surveyed downstream of the culvert.

The surveyed approach section (APTEM) was moved along the approach channel slope $(0.0041 \mathrm{ft} / \mathrm{ft})$ to establish the modelled approach section (APPRO), one culvert length upstream of the upstream face as recommended by Shearman and others (1986). This location provides a consistent method for determining scour variables.

For this site, the culvert geometry was modified to create an "equivalent" bridge opening having the same area as the culvert. Bridge routines were then used to approximate the culvert flow with road overflow. 


\section{Bridge Hydraulics Summary}

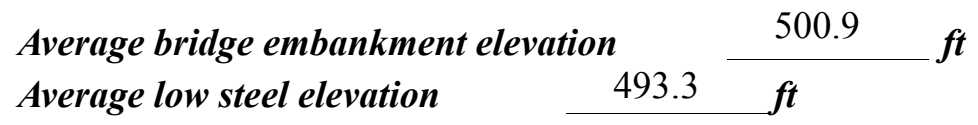

100-year discharge $\quad 2,500 \quad \mathrm{ft}^{3} / \mathrm{s}$

Water-surface elevation in bridge opening $\quad 493.3 \quad f t$

Road overtopping? ___ Yes Discharge over road _ $1,110,3 / s$

\begin{tabular}{llll} 
Area of flow in bridge opening & 166 & $\boldsymbol{f t}^{2}$ \\
\cline { 2 - 3 } Average velocity in bridge opening & 8.3 & $\boldsymbol{f t} / \mathrm{s}$
\end{tabular}

$\begin{array}{llll}\text { Maximum WSPRO tube velocity at bridge } & 10.9 \mathrm{ft} / \mathrm{s}\end{array}$

Water-surface elevation at Approach section with bridge 495.0

$\begin{array}{ll}\text { Water-surface elevation at Approach section without bridge } & 491.2\end{array}$

Amount of backwater caused by bridge $\quad 3.8$ it

500-year discharge $\quad 3,580 \quad \mathrm{ft}^{3} / \mathrm{s}$

Water-surface elevation in bridge opening $\quad 493.3 \mathrm{ft}$

Road overtopping? ___ Yes Discharge over road _ $2,050, \ldots$

Area of flow in bridge opening $\quad 166 \quad \mathrm{ft}^{2}$

Average velocity in bridge opening $\quad 9.2 \mathrm{ft} / \mathrm{s}$

Maximum WSPRO tube velocity at bridge 12.1 , s

Water-surface elevation at Approach section with bridge 495.7

Water-surface elevation at Approach section without bridge $\quad 492.1$

Amount of backwater caused by bridge $\quad 3.6, t$

Incipient overtopping discharge $\quad 1,000 \mathrm{ft}^{3} / \mathrm{s}$

Water-surface elevation in bridge opening 488.2 t

Area of flow in bridge opening $\quad 88 \quad \mathrm{ft}^{2}$

Average velocity in bridge opening $\quad 11.4 \quad \mathrm{ft} / \mathrm{s}$

Maximum WSPRO tube velocity at bridge $\quad 14.9 \quad \mathrm{ft} / \mathrm{s}$

Water-surface elevation at Approach section with bridge

Water-surface elevation at Approach section without bridge

493.2

Amount of backwater caused by bridge $\quad 3.1$, t

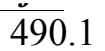




\section{Scour Analysis Summary}

\section{Special Conditions or Assumptions Made in Scour Analysis}

Scour depths were computed using the general guidelines described in Hydraulic Engineering Circular 18 (Richardson and Davis, 1995). Scour depths were calculated assuming an infinite depth of erosive material and a homogeneous particle-size distribution. The results of the scour analyses for the 100- and 500-year discharges are presented in tables 1 and 2 and the scour depths are shown graphically in figure 8 .

Contraction scour for the incipient roadway-overtopping discharge was computed by use of the Laursen clear-water contraction scour equation (Richardson and Davis, 1995, p. 32 , equation 20). At this site, the 100- and 500-year discharges resulted in unsubmerged orifice flow. Contraction scour at bridges with orifice flow is best estimated by use of the Chang pressure-flow scour equation (oral communication, J. Sterling Jones, October 4, 1996). Thus, contraction scour for these discharges was computed by use of the Chang equation (Richardson and Davis, 1995, p. 145-146).

For comparison, contraction scour for the discharges resulting in orifice flow also was computed by use of the Laursen clear-water contraction scour equation and the Umbrell pressure-flow equation (Richardson and Davis, 1995, p. 144). Results from these computations are presented in appendix F. Furthermore, for those discharges which resulted in unsubmerged orifice flow, contraction scour was computed by substituting estimates for the depth of flow at the culvert outlet in the contraction scour equations. Results with respect to these substitutions are provided in appendix F.

Abutment scour for the right abutment was computed by use of the Froehlich equation (Richardson and Davis, 1995, p. 48, equation 28). Variables for the Froehlich equation include the Froude number of the flow approaching the embankments, the length of the embankment blocking flow, and the depth of flow approaching the embankment less any roadway overtopping.

Scour at the left abutment was computed by use of the HIRE equation (Richardson and Davis, 1995, p. 49, equation 29) because the HIRE equation is recommended when the length to depth ratio of the embankment blocking flow exceeds 25 . The variables used by the HIRE abutment-scour equation are defined the same as those defined for the Froehlich abutment-scour equation. 


\section{Scour Results}

Contraction scour:

Main channel

Live-bed scour

Clear-water scour

Depth to armoring

Left overbank

Right overbank

Local scour:

Abutment scour

Left abutment

Right abutment

Pier scour

Pier 1

Pier 2

Pier 3 100-year
discharge 500-year discharge

(Scour depths in feet)

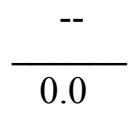

$6.1^{-}$
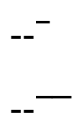

9.5

$17.1-$

11.3

19.2-

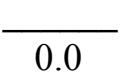

$9.3^{-}$
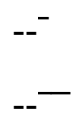

Incipient overtopping discharge

Abutments:

Left abutment

Right abutment

Piers:

Pier 1

Pier 2

\section{Riprap Sizing}

\section{0-year discharge}

$$
2.0
$$

2.0
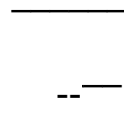

$--$
Incipient

500-year discharge ( $D_{50}$ in feet) 2.2

1.6

$$
2.2
$$

1.6
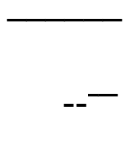

overtopping discharge
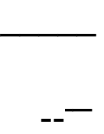

5.3

12.9- 


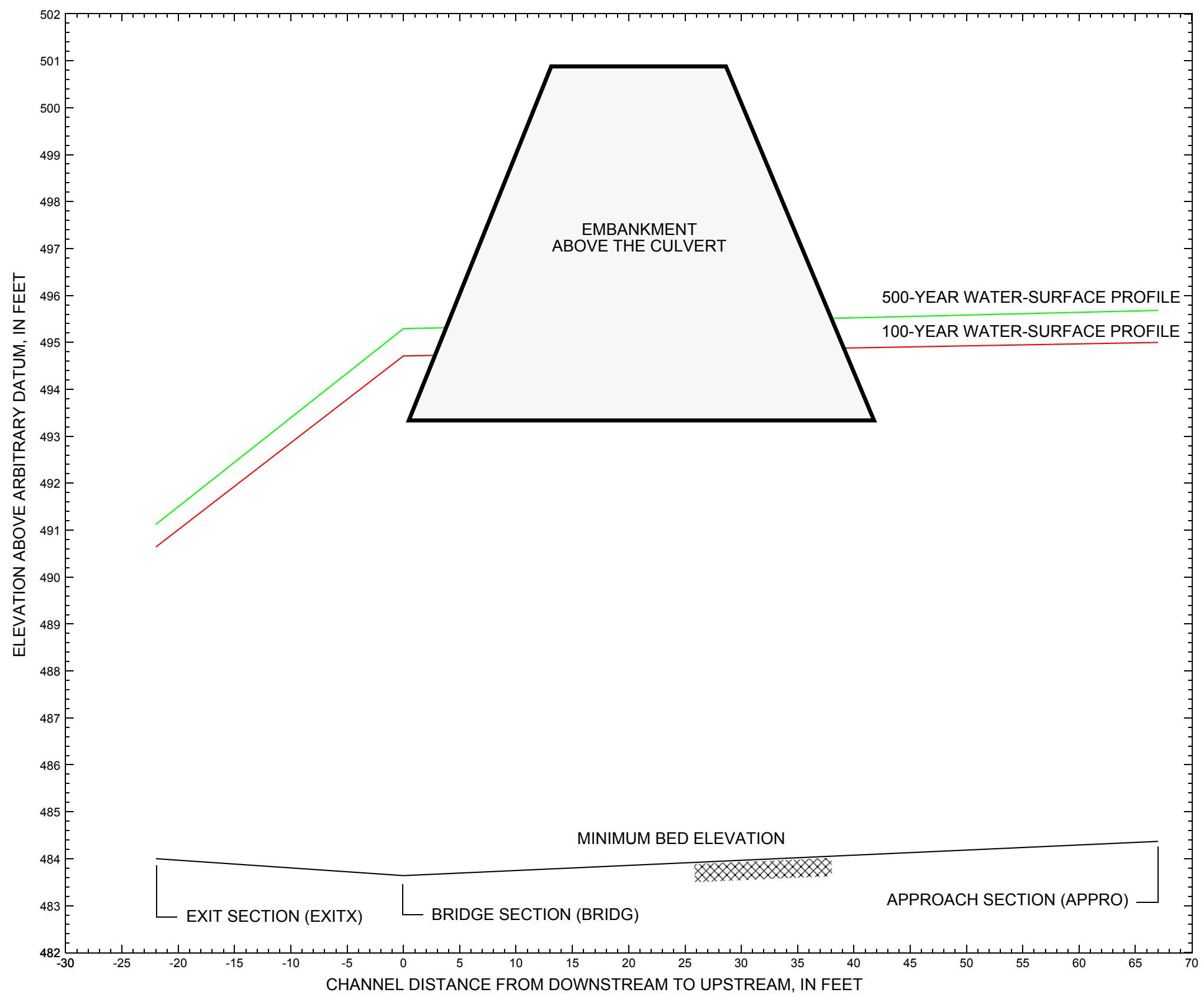

Figure 7. Water-surface profiles for the 100- and 500-year discharges at structure READTH00510029 on Town Highway 51, crossing Mill Brook, Reading, Vermont. 


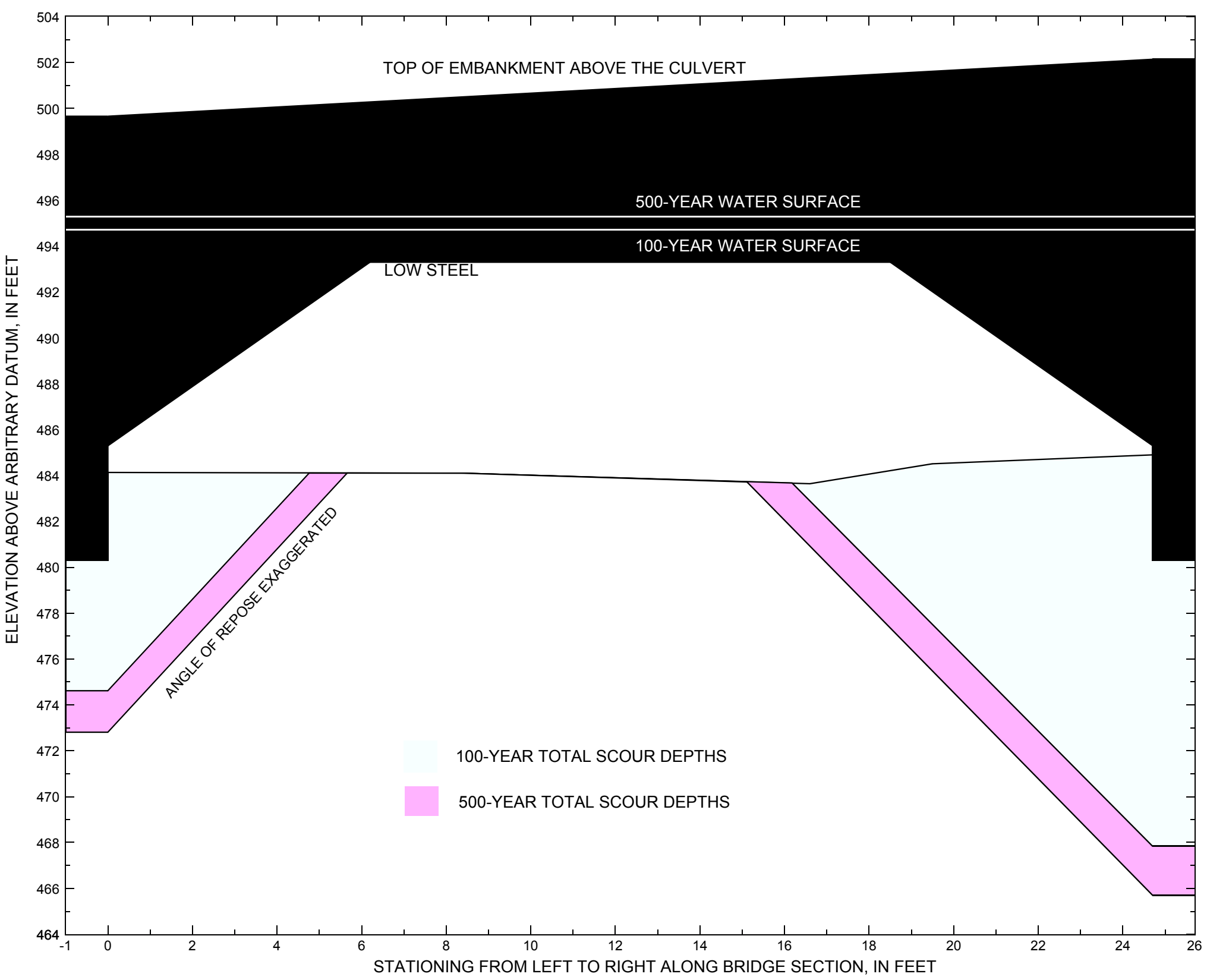

Figure 8. Scour elevations for the 100- and 500-year discharges at structure READTH00510029 on Town Highway 51, crossing Mill Brook, Reading, Vermont. 


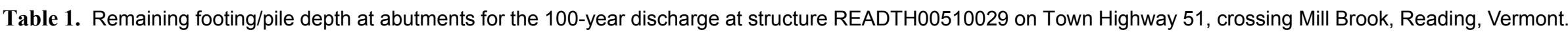
[VTAOT, Vermont Agency of Transportation; --, no data]

\begin{tabular}{|c|c|c|c|c|c|c|c|c|c|c|c|}
\hline Description & Station $^{1}$ & $\begin{array}{l}\text { VTAOT } \\
\text { minimum } \\
\text { low-chord } \\
\text { elevation } \\
\text { (feet) }\end{array}$ & $\begin{array}{l}\text { Surveyed } \\
\text { minimum } \\
\text { low-chord } \\
\text { elevation } \\
\text { (feet) }\end{array}$ & $\begin{array}{c}\text { Bottom of } \\
\text { footing/pile } \\
\text { elevation }{ }^{2} \\
\text { (feet) }\end{array}$ & $\begin{array}{c}\text { Channel } \\
\text { elevation at } \\
\text { abutment/ } \\
\text { pier }{ }^{2} \\
\text { (feet) }\end{array}$ & $\begin{array}{l}\text { Contraction } \\
\text { scour depth } \\
\text { (feet) }\end{array}$ & $\begin{array}{l}\text { Abutment } \\
\text { scour } \\
\text { depth } \\
\text { (feet) }\end{array}$ & $\begin{array}{l}\text { Pier } \\
\text { scour } \\
\text { depth } \\
\text { (feet) }\end{array}$ & $\begin{array}{l}\text { Depth of } \\
\text { total scour } \\
\text { (feet) }\end{array}$ & $\begin{array}{c}\text { Elevation of } \\
\text { scour }^{2} \\
\text { (feet) }\end{array}$ & $\begin{array}{c}\text { Remaining } \\
\text { footing/pile } \\
\text { depth } \\
\text { (feet) }\end{array}$ \\
\hline \multicolumn{12}{|c|}{100 -year discharge is 2,500 cubic-feet per second } \\
\hline Left abutment & 0.0 & -- & 493.3 & 480.3 & 484.1 & 0.0 & 9.5 & -- & 9.5 & 474.6 & -5.7 \\
\hline Right abutment & 24.7 & -- & 493.3 & 480.3 & 484.9 & 0.0 & 17.1 & -- & 17.1 & 467.8 & -12.5 \\
\hline
\end{tabular}

1.Measured along the face of the most constricting side of the culvert

2.Arbitrary datum for this study.

Table 2. Remaining footing/pile depth at abutments for the 500-year discharge at structure READTH00510029 on Town Highway 51, crossing Mill Brook, Reading, Vermont. [VTAOT, Vermont Agency of Transportation; --, no data]

\begin{tabular}{|c|c|c|c|c|c|c|c|c|c|c|c|}
\hline Description & Station $^{1}$ & $\begin{array}{l}\text { VTAOT } \\
\text { minimum } \\
\text { low-chord } \\
\text { elevation } \\
\text { (feet) }\end{array}$ & $\begin{array}{l}\text { Surveyed } \\
\text { minimum } \\
\text { low-chord } \\
\text { elevation }{ }^{2} \\
\text { (feet) }\end{array}$ & $\begin{array}{c}\text { Bottom of } \\
\text { footing/pile } \\
\text { elevation }{ }^{2} \\
\text { (feet) }\end{array}$ & $\begin{array}{c}\text { Channel } \\
\text { elevation at } \\
\text { abutment/ } \\
\text { pier }^{2} \\
\text { (feet) }\end{array}$ & $\begin{array}{c}\text { Contraction } \\
\text { scour depth } \\
\text { (feet) }\end{array}$ & $\begin{array}{l}\text { Abutment } \\
\text { scour } \\
\text { depth } \\
\text { (feet) }\end{array}$ & $\begin{array}{l}\text { Pier } \\
\text { scour } \\
\text { depth } \\
\text { (feet) }\end{array}$ & $\begin{array}{l}\text { Depth of } \\
\text { total scour } \\
\text { (feet) }\end{array}$ & $\begin{array}{c}\text { Elevation of } \\
\text { scour }^{2} \\
\text { (feet) }\end{array}$ & $\begin{array}{l}\text { Remaining } \\
\text { footing/pile } \\
\text { depth } \\
\text { (feet) }\end{array}$ \\
\hline \multicolumn{12}{|c|}{500 -year discharge is 3,580 cubic-feet per second } \\
\hline Left abutment & 0.0 & -- & 493.3 & 480.3 & 484.1 & 0.0 & 11.3 & -- & 11.3 & 472.8 & -7.5 \\
\hline Right abutment & 24.7 & -- & 493.3 & 480.3 & 484.9 & 0.0 & 19.2 & -- & 19.2 & 465.7 & -14.6 \\
\hline
\end{tabular}

1.Measured along the face of the most constricting side of the culvert.

2.Arbitrary datum for this study. 


\section{SELECTED REFERENCES}

Arcement, G.J., Jr., and Schneider, V.R., 1989, Guide for selecting Manning's roughness coefficients for natural channels and flood plains: U.S. Geological Survey Water-Supply Paper 2339, 38 p.

Barnes, H.H., Jr., 1967, Roughness characteristics of natural channels: U.S. Geological Survey Water-Supply Paper 1849,213 p.

Benson, M. A., 1962, Factors Influencing the Occurrence of Floods in a Humid Region of Diverse Terrain: U.S. Geological Survey WaterSupply Paper 1580-B, 64 p.

Brown, S.A. and Clyde, E.S., 1989, Design of riprap revetment: Federal Highway Administration Hydraulic Engineering Circular No. 11, Publication FHWA-IP-89-016, 156 p.

Federal Highway Administration, 1983, Runoff estimates for small watersheds and development of sound design: Federal Highway Administration Report FHWA-RD-77-158.

Federal Highway Administration, 1993, Stream Stability and Scour at Highway Bridges: Participant Workbook: Federal Highway Administration Report FHWA-HI-91-011.

Froehlich, D.C., 1989, Local scour at bridge abutments in Ports, M.A., ed., Hydraulic Engineering--Proceedings of the 1989 National Conference on Hydraulic Engineering: New York, American Society of Civil Engineers, p. 13-18.

Hayes, D.C.,1993, Site selection and collection of bridge-scour data in Delaware, Maryland, and Virginia: U.S. Geological Survey WaterResources Investigation Report 93-4017, 23 p.

Interagency Advisory Committee on Water Data, 1982, Guidelines for determining flood flow frequency: U.S. Geological Survey, Bulletin 17B of the Hydrology Subcommittee, 190 p.

Johnson, C.G. and Tasker, G.D.,1974, Progress report on flood magnitude and frequency of Vermont streams: U.S. Geological Survey OpenFile Report 74-130, 37 p.

Lagasse, P.F., Schall, J.D., Johnson, F., Richardson, E.V., Chang, F., 1995, Stream Stability at Highway Structures: Federal Highway Administration Hydraulic Engineering Circular No. 20, Publication FHWA-IP-90-014, 144 p.

Laursen, E.M., 1960, Scour at bridge crossings: Journal of the Hydraulics Division, American Society of Civil Engineers, v. 86, no. HY2, p. 39-53.

Potter, W. D., 1957a, Peak rates of runoff in the Adirondack, White Mountains, and Maine woods area, Bureau of Public Roads

Potter, W. D., 1957b, Peak rates of runoff in the New England Hill and Lowland area, Bureau of Public Roads

Richardson, E.V. and Davis, S.R., 1995, Evaluating scour at bridges: Federal Highway Administration Hydraulic Engineering Circular No. 18, Publication FHWA-IP-90-017, 204 p.

Richardson, E.V., Simons, D.B., and Julien, P.Y., 1990, Highways in the river environment: Federal Highway Administration Publication FHWA-HI-90-016.

Ritter, D.F., 1984, Process Geomorphology: W.C. Brown Co., Debuque, Iowa, 603 p.

Shearman, J.O., 1990, User's manual for WSPRO--a computer model for water surface profile computations: Federal Highway Administration Publication FHWA-IP-89-027, 187 p.

Shearman, J.O., Kirby, W.H., Schneider, V.R., and Flippo, H.N., 1986, Bridge waterways analysis model; research report: Federal Highway Administration Publication FHWA-RD-86-108, 112 p.

Talbot, A.N., 1887, The determination of water-way for bridges and culverts.

U.S. Geological Survey, 1972, Cavendish, Vermont 7.5 Minute Series quadrangle map: U.S. Geological Survey Topographic Maps, Photoinspected 1983, Scale 1:24,000. 


\section{APPENDIX A: \\ WSPRO INPUT FILE}




\section{WSPRO INPUT FILE}

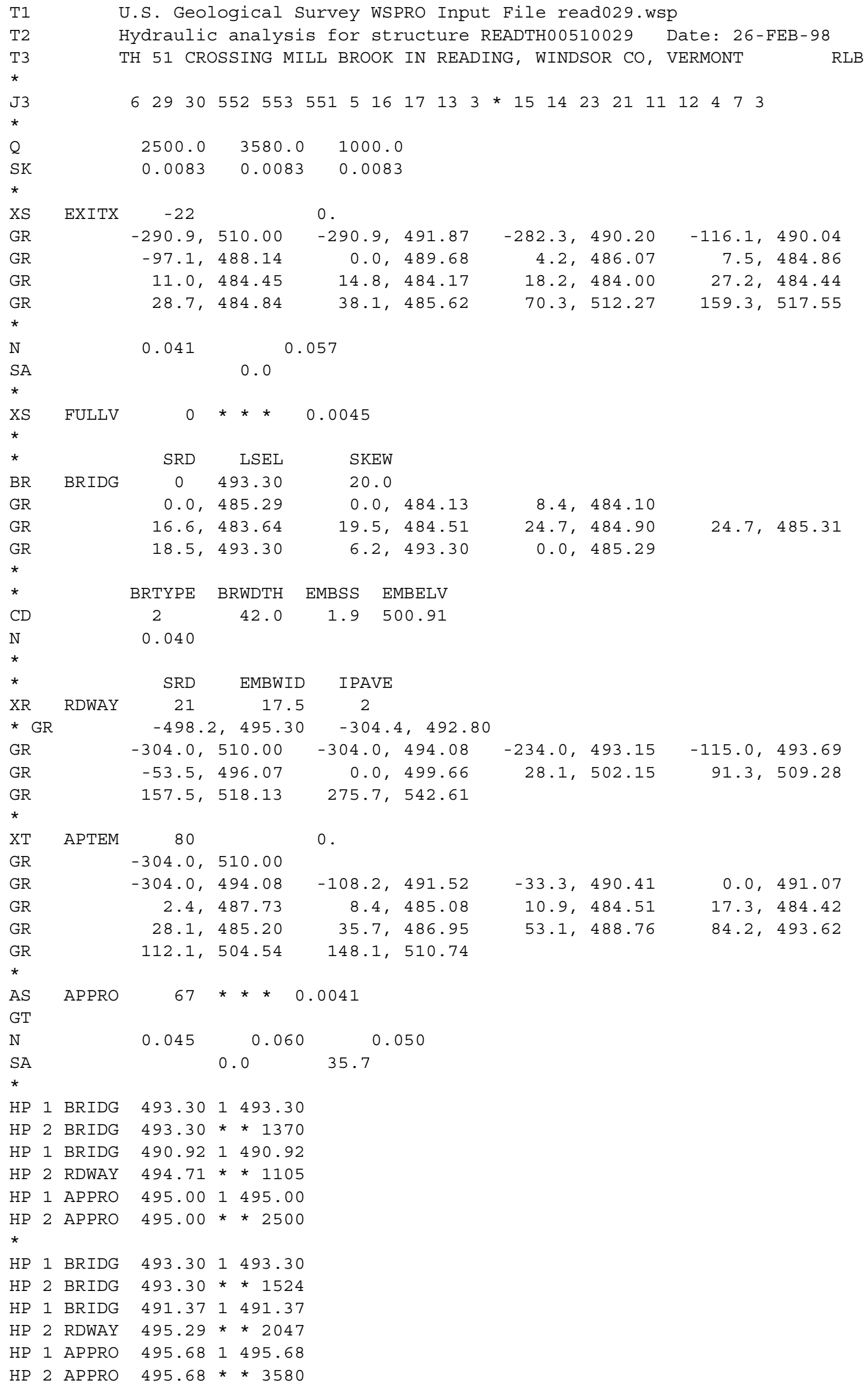




\section{APPENDIX B: \\ WSPRO OUTPUT FILE}




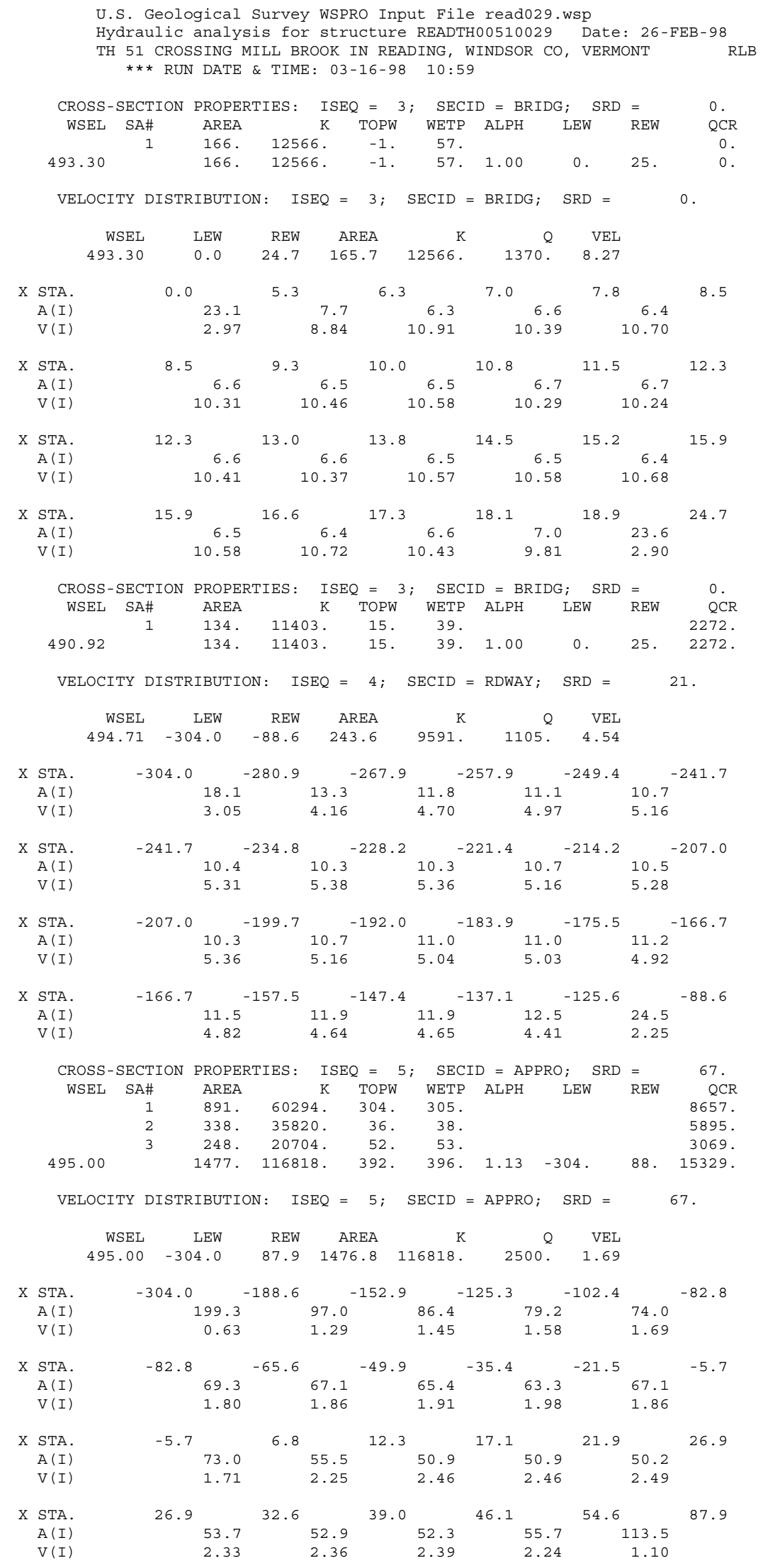




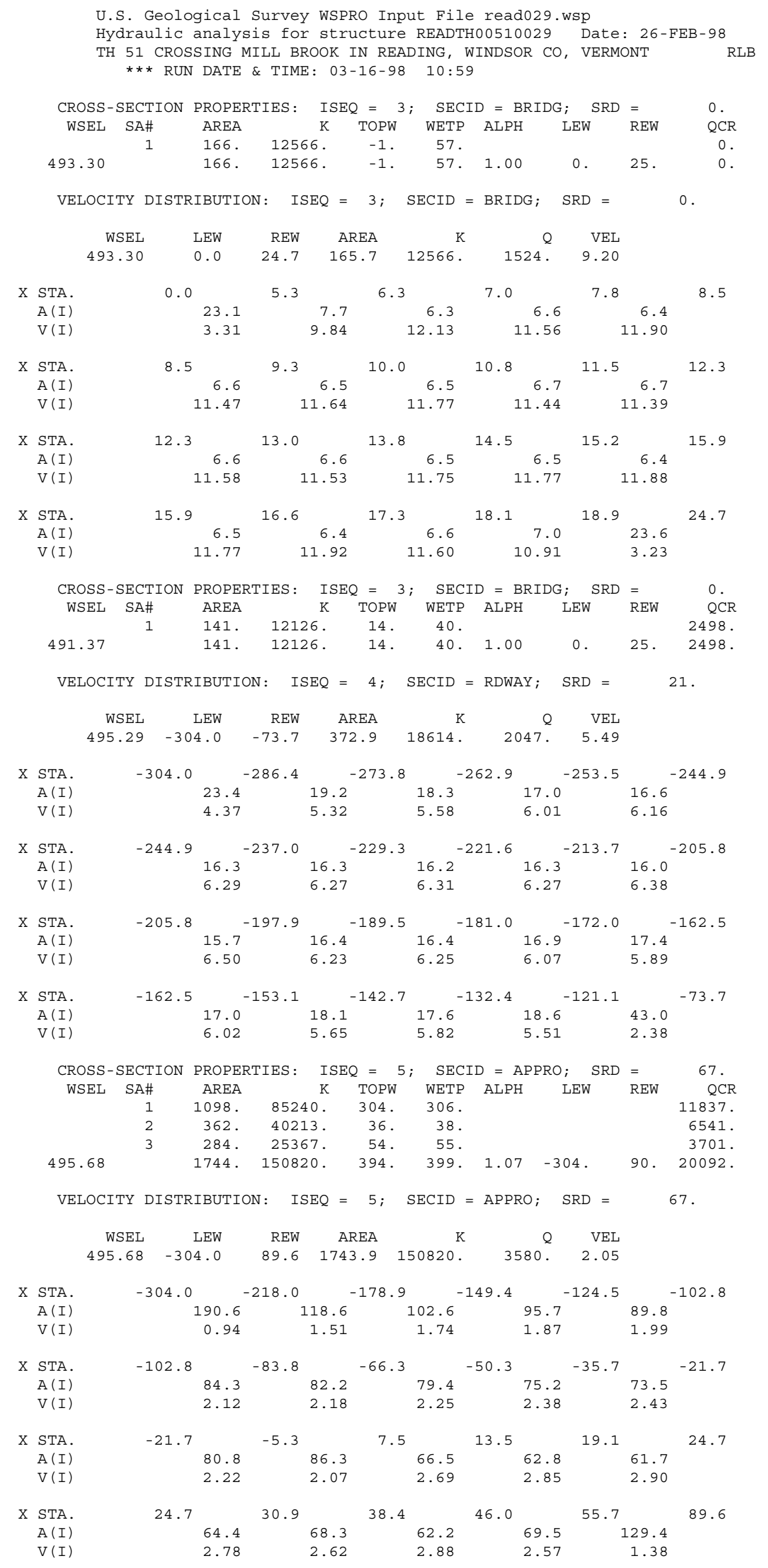


WSPRO OUTPUT FILE (continued)

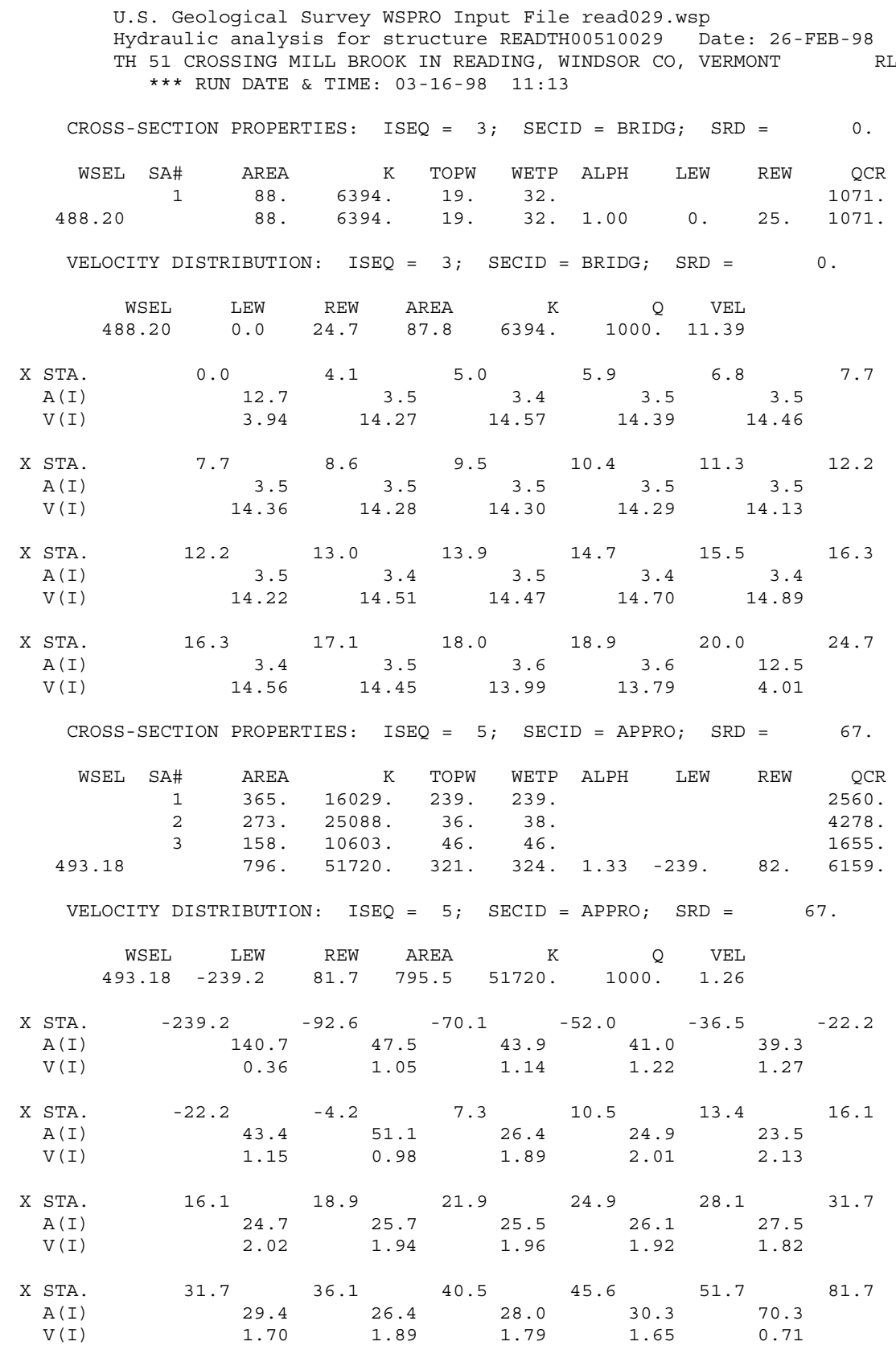


WSPRO OUTPUT FILE (continued)

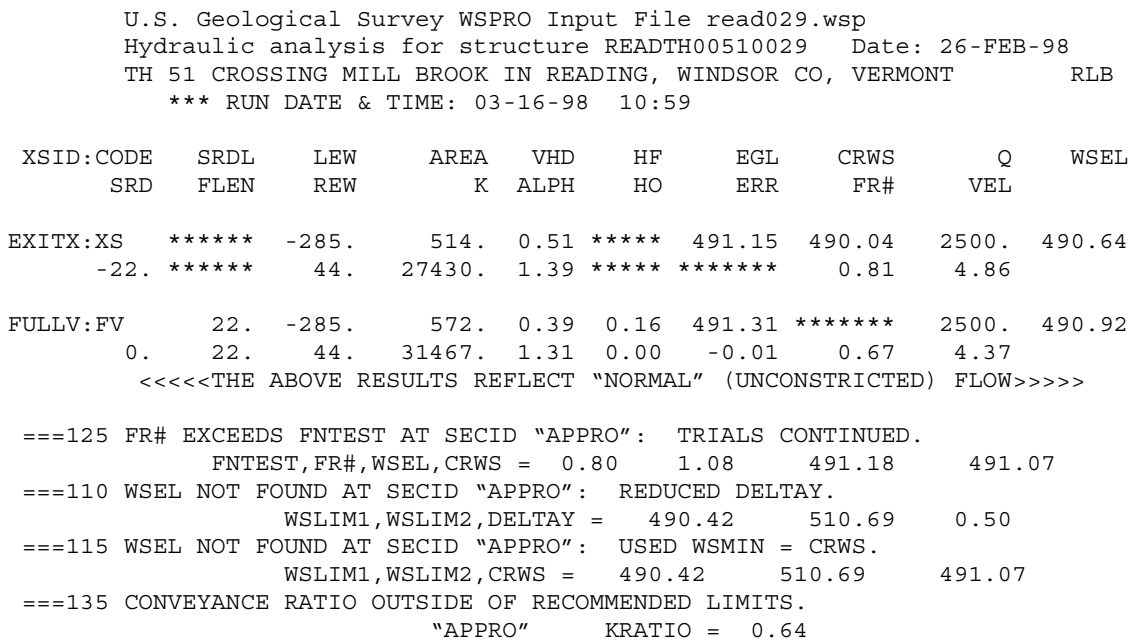


WSPRO OUTPUT FILE (continued)

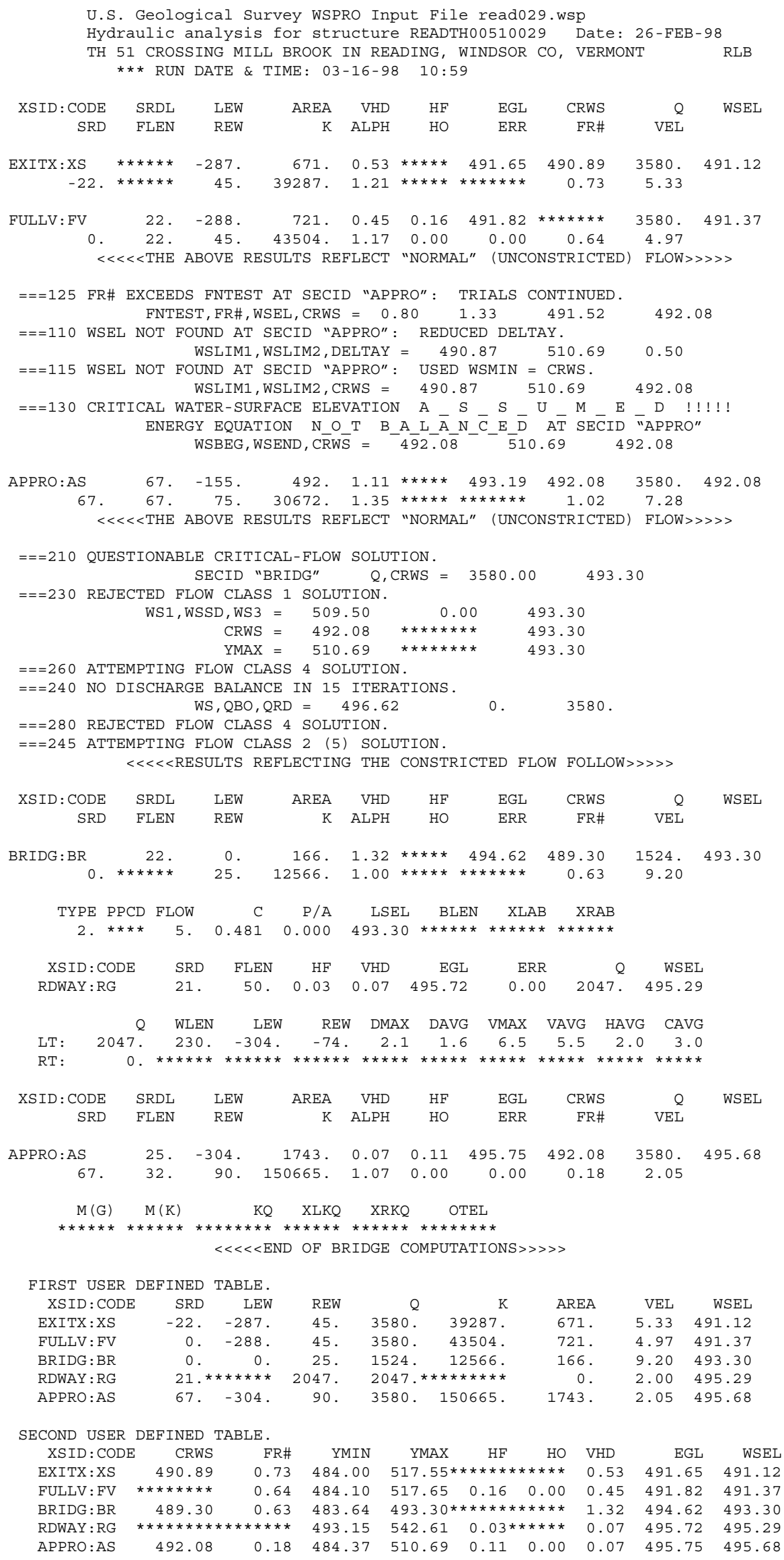


WSPRO OUTPUT FILE (continued)

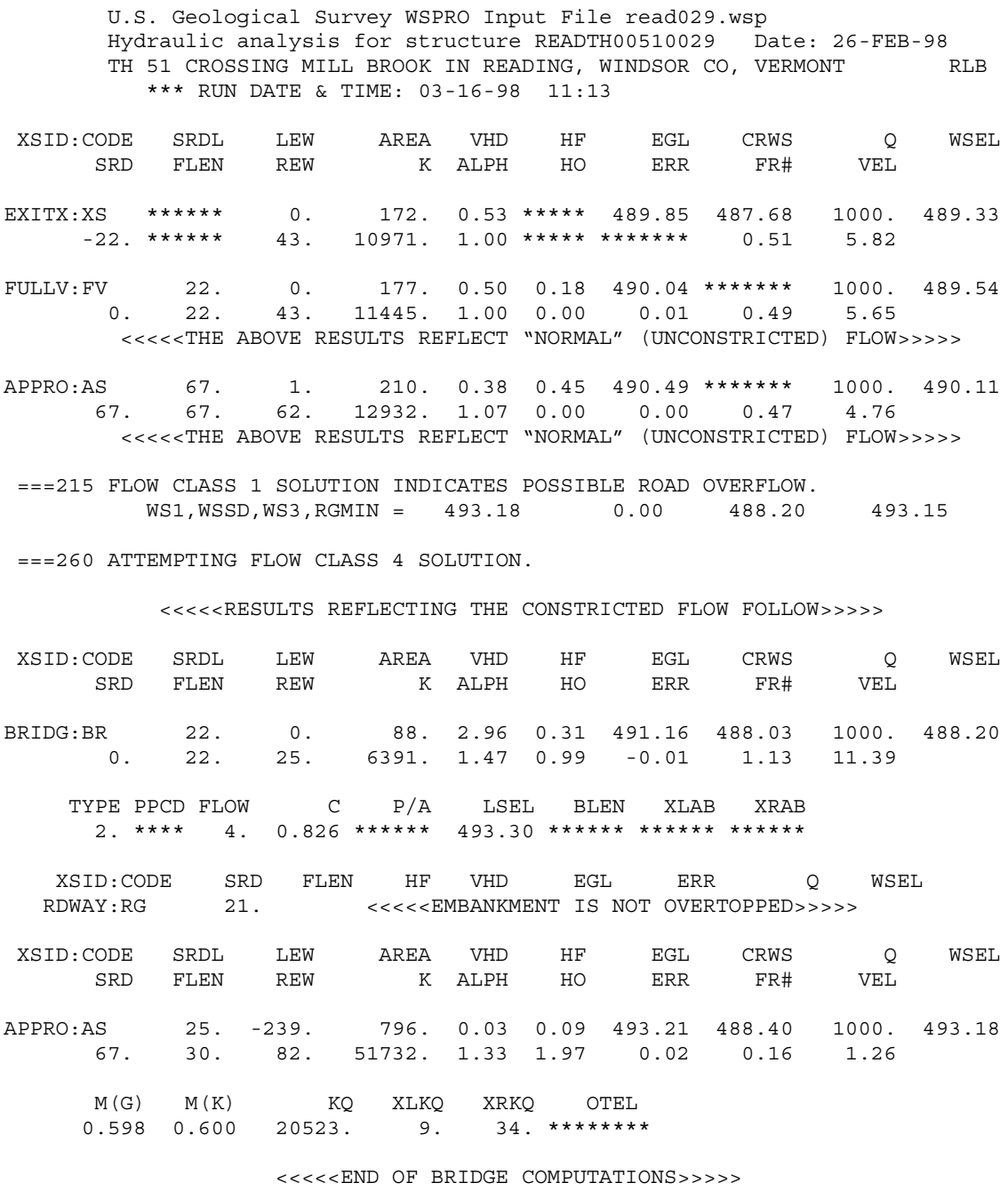

FIRST USER DEFINED TABLE.

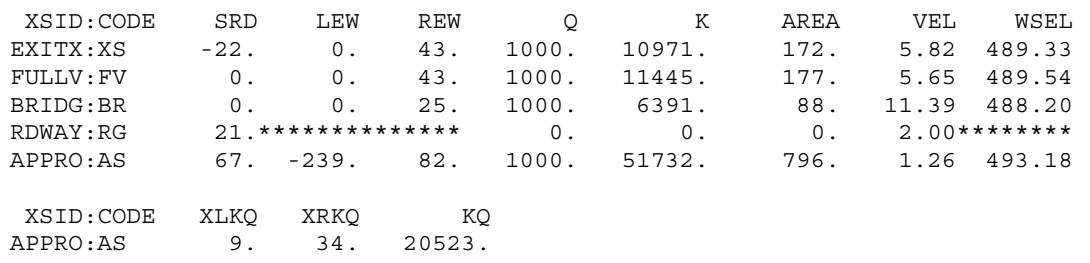

SECOND USER DEFINED TABLE.

$\begin{array}{lrrrrrrrrr}\text { XSID:CODE } & \text { CRWS } & \text { FR\# } & \text { YMIN } & \text { YMAX } & \text { HF } & \text { HO } & \text { VHD } & \text { EGL } & \text { WSEL } \\ \text { EXITX:XS } & 487.68 & 0.51 & 484.00 & 517.55 * * * * * * * * * * & 0.53 & 489.85 & 489.33 \\ \text { FULLV:FV } & * * * * * * * * & 0.49 & 484.10 & 517.65 & 0.18 & 0.00 & 0.50 & 490.04 & 489.54 \\ \text { BRIDG:BR } & 488.03 & 1.13 & 483.64 & 493.30 & 0.31 & 0.99 & 2.96 & 491.16 & 488.20 \\ \text { RDWAY:RG } & * * * * * * * * * * * * * * * * & 493.15 & 542.61 & 0.02 * * * * * * & 0.03 & 493.20 * * * * * * * \\ \text { APPRO:AS } & 488.40 & 0.16 & 484.37 & 510.69 & 0.09 & 1.97 & 0.03 & 493.21 & 493.18\end{array}$




\section{APPENDIX C:}

\section{BED-MATERIAL PARTICLE-SIZE DISTRIBUTION}




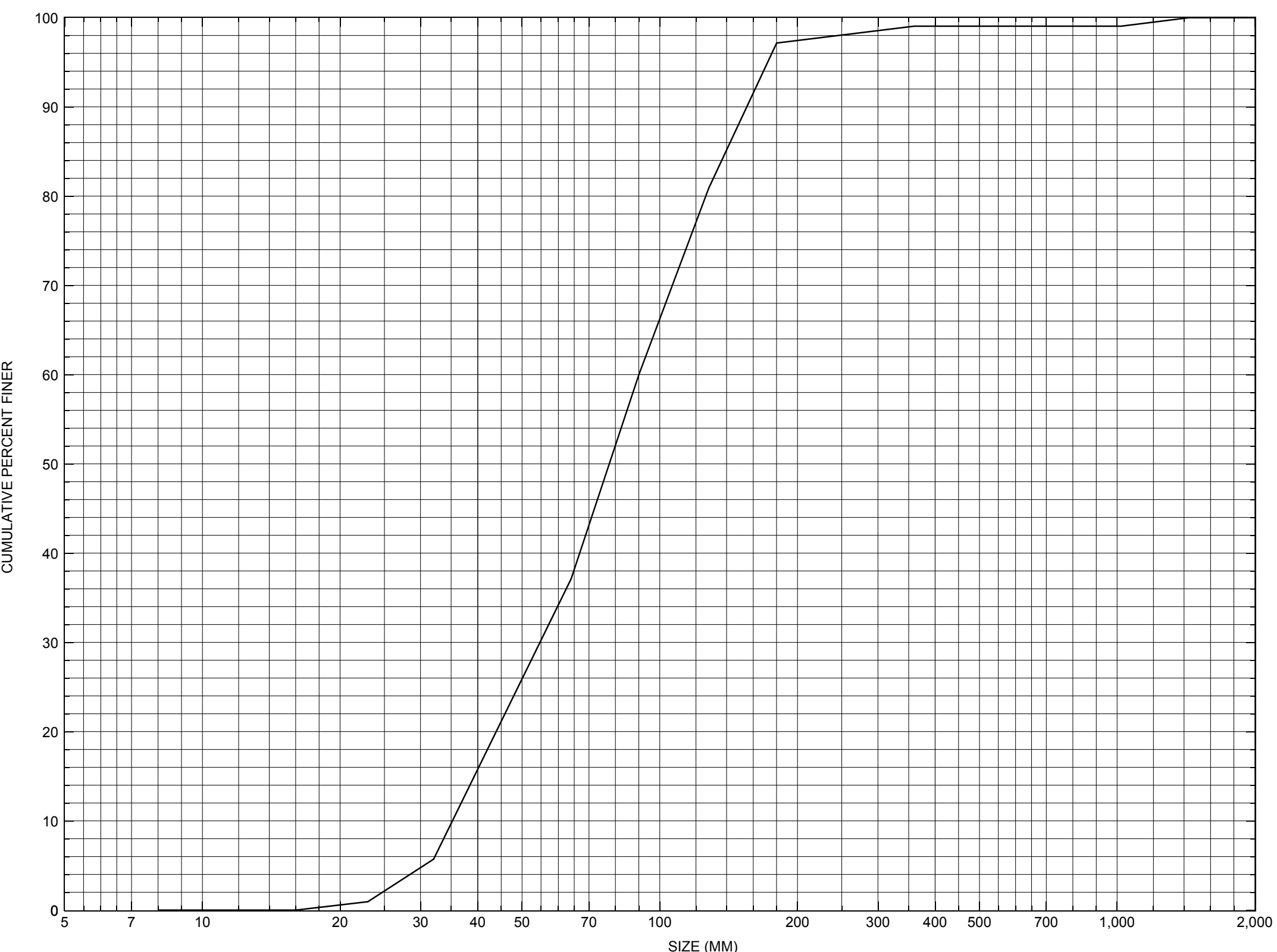

Appendix C: Bed material particle size distribution for a pebble count in the channel approach of structure READTH00510029, in Reading, Vermont. 


\section{APPENDIX D: \\ HISTORICAL DATA FORM}




\section{Structure Number READTH00510029}

\section{General Location Descriptive}

Data collected by (First Initial, Full last name) $\mathbf{E}$. BOEHMLER

Date $(M M / D D / Y Y) \_\mathbf{0 3} / \underline{\mathbf{0 8}} / \underline{\mathbf{9 5}}$

Highway District Number (I - 2; nn) $\mathbf{0 4}$

Town (FIPS place code; I - 4; nnnnn) $\mathbf{5 8 3 7 5}$

Waterway (I - 6) MILL BROOK

Route Number $\underline{\text { TH051 }}$

Topographic Map Cavendish

Latitude (I - 16; nnnn.n) $\mathbf{4 3 2 9 2}$
County (FIPS county code; I - 3; nnn)

Mile marker (I - 11; nnn.nnn) $\mathbf{0 0 0 0 0 0}$

Road Name (I - 7): -

Vicinity (I - 9) 0.06 MI TO JCT W VT106

Hydrologic Unit Code: $\mathbf{0 1 0 8 0 1 0 4}$

Longitude (i - 17; nnnnn.n) $\mathbf{7 2 3 3 2}$

\section{Select Federal Inventory Codes}

FHWA Structure Number (I - 8) 10141400291414

Maintenance responsibility $(I-21 ; n n) \quad \mathbf{0 3}$

Year built (I - 27; YYYY) 1963

Average daily traffic, ADT (I - 29; nnnnnn) 000040

Year of ADT (I - 30; YY) $\mathbf{9 1}$

Opening skew to Roadway $(I-34 ; n n) \quad \mathbf{0 0}$

Operational status $(I-41 ; X) \quad \mathbf{A}$

Structure type (I - 43; nnn) $\mathbf{3 1 9}$

Approach span structure type $(I-44 ; n n n)$ 000

Number of spans (I - 45; nnn) $\mathbf{0 0 1}$

Number of approach spans (I - 46; nnnn) $\mathbf{0 0 0 0}$

Comments:

The structural inspection report of 9/10/93 indicates the structure is a multi-plate arch culvert. Both concrete abutment footings are exposed at the surface. At the upstream end of the left abutment footing there is a deep scour hole. The footing at the left abutment may be slightly undermined. There is large boulder fill in this area for protection. The waterway is noted as "somewhat poorly aligned" with the structure. The flow is directed into the upstream end of the left abutment and then deflected into the downstream end of the right abutment. The streambed material is composed of mainly stone and gravel. There is a point bar noted on the left bank just downstream of the structure. Road embankment erosion and settlement are indicated in the report as not evident. The culvert has mitered openings. 


\section{Bridge Hydrologic Data}

Is there hydrologic data available? $\underline{\mathbf{N}}$ if No, type ctrl-n $h \quad$ VTAOT Drainage area $\left(m i^{2}\right)$ : -

Terrain character:

Stream character \& type: -

Streambed material: Stones and gravel

Discharge Data (cfs): $\quad Q_{2.33}$

$$
\mathrm{Q}_{50}
$$

Record flood date $(M M / D D / Y Y):-$

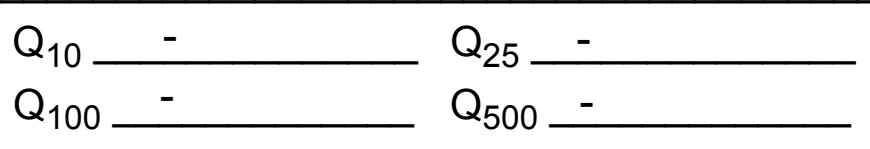

Water surface elevation $(f t):-$

Estimated Discharge (cfs): Velocity at $\mathrm{Q}-$ $(\mathrm{ft} / \mathrm{s}):$

Ice conditions (Heavy, Moderate, Light) : -

Debris (Heavy, Moderate, Light):

The stage increases to maximum highwater elevation (Rapidly, Not rapidly):

The stream response is (Flashy, Not flashy):

Describe any significant site conditions upstream or downstream that may influence the stream's stage: -

Watershed storage area (in percent): - $\%$

The watershed storage area is: - _ (1-mainly at the headwaters; 2- uniformly distributed; 3-immediatly upstream oi the site)

Water Surface Elevation Estimates for Existing Structure:

\begin{tabular}{|l|l|l|l|l|l|}
\hline Peak discharge frequency & $Q_{2.33}$ & $Q_{10}$ & $Q_{25}$ & $Q_{50}$ & $Q_{100}$ \\
Water surface elevation (ft)) & - & - & - & - & - \\
Velocity (ft/sec) & - & - & - & - & - \\
\hline
\end{tabular}

Long term stream bed changes: -

Is the roadway overtopped below the $\mathrm{Q}_{100}$ ? (Yes, No, Unknown): $\mathbf{U} \quad$ Frequency: -

Relief Elevation $(f t)$ :

Discharge over roadway at $Q_{100}\left(f^{3} / \mathrm{sec}\right)$ :

Are there other structures nearby? (Yes, No, Unknown): Upstream distance (miles): Town: If No or Unknown, type ctrl-n os Highway No. : Structure No. : Year Built:

Clear span (ft): Clear Height (ft): Full Waterway $\left(f^{2}\right)$ : 
Downstream distance (miles): Town: Year Built:

Highway No. : Structure No. : Structure Type:

Clear span (ft): Clear Height $(f t)$ : Full Waterway $\left(f^{2}\right):$

Comments:

\section{USGS Watershed Data}

Watershed Hydrographic Data

Drainage area $(D A)$

Watershed storage (ST) $\mathrm{mi}^{2}$ Lake/pond/swamp area 0.01 $\mathrm{mi}^{2}$

Bridge site elevation 0.1 min $\%$

Main channel length $\mathbf{5 . 5 3}$ $\mathrm{ft}$

Headwater elevation 2290 $\mathrm{ft}$ $10 \%$ channel length elevation $\mathbf{9 8 0}$ $\mathrm{ft} \quad 85 \%$ channel length elevation 1880 $\mathrm{ft}$ Main channel slope (S) $227.61 \mathrm{ft} / \mathrm{mi}$

Watershed Precipitation Data

Average site precipitation in Average headwater precipitation in

Maximum 2yr-24hr precipitation event $(124,2)$ in

Average seasonal snowfall (Sn) $\mathrm{ft}$ 


\section{Bridge Plan Data}

Are plans available? $\mathbf{Y}$ If no, type ctrl-n pl Date issued for construction (MM/YYYY): $\mathbf{0 4} / \mathbf{1 9 6 3}$ Project Number TF 7/1962 Minimum channel bed elevation: 4 775.5

Low superstructure elevation: USLAB $\underline{\mathbf{4 7 7 . 1 2}}$ DSLAB $\underline{\mathbf{4 7 6 . 5 2}}$ USRAB $\underline{\mathbf{4 7 7 . 0 4}}$ DSRAB $\underline{\mathbf{4 7 6 . 4 4}}$ Benchmark location description:

BM\#1, Spike in root of an 18 inch elm tree, located about 75 feet right bankward from the right abutment on the roadway and about 15 feet from the roadway centerline upstream, elevation 500.0 feet.

Reference Point (MSL, Arbitrary, Other): Arbitrary Datum (NAD27, NAD83, Other): Arbitrary Foundation Type: 4 (1-Spreadfooting; 2-Pile; 3- Gravity; 4-Unknown)

If 1 : Footing Thickness $\mathbf{5 . 0} \quad$ Footing bottom elevation: $\underline{\mathbf{5 7 1 . 7 9 *}}$

If 2: Pile Type: ___ (1-Wood; 2-Steel or metal; 3-Concrete) Approximate pile driven length: -

If 3: Footing bottom elevation: -

Is boring information available? $\underline{\mathbf{Y}}$ If no, type ctrl-n bi Number of borings taken: $\underline{4}$

Foundation Material Type: 1 (1-regolith, 2-bedrock, 3-unknown)

Briefly describe material at foundation bottom elevation or around piles:

The footings are set in a dense to very dense sand with some gravel and silt.

Comments:

The low superstructure elevations given are for the tops of the concrete footings. The plans showed the channel was to be excavated and leveled at $476.1 \mathrm{ft}$ at the upstream end and $475.5 \mathrm{ft}$ at the downstream end with a $1 \%$ grade or slope.

*The upstream footing bottom elevation is $472.09 \mathrm{ft}$ and the downstream end is at an elevation of $471.48 \mathrm{ft}$. 


\section{Cross-sectional Data}

Is cross-sectional data available? $\underline{\mathbf{Y}}$

If no, type ctrl-n xs

Source (FEMA, VTAOT, Other)? VTAOT

Comments: Upstream arch face channel cross section. *Point of contact where the steel arch meets the concrete footing.

\begin{tabular}{|l|l|l|l|l|l|l|l|l|l|l|l|}
\hline Station & -12.5 & -12.5 & -7.5 & +2.5 & +5.5 & +12.5 & +12.5 & - & - & - & - \\
\hline Feature & $\begin{array}{l}\text { footing } \\
\text { bottom }\end{array}$ & LCL* & - & - & - & LCR* & $\begin{array}{l}\text { footing } \\
\text { bottom }\end{array}$ & - & - & - & - \\
\hline $\begin{array}{l}\text { Low chord } \\
\text { elevation }\end{array}$ & & 476.6 & - & - & - & 476.6 & & - & - & - & - \\
\hline $\begin{array}{l}\text { Bed } \\
\text { elevation }\end{array}$ & 472 & 475.3 & 474.7 & 475.5 & 476.0 & 476.0 & 472.0 & - & - & - & - \\
\hline $\begin{array}{l}\text { Low chord } \\
\text { to bed }\end{array}$ & - & - & - & - & - & - & - & - & - & - & - \\
\hline Station & - & - & - & - & - & - & - & - & - & - & - \\
\hline Feature & - & - & - & - & - & - & - & - & - & - & - \\
\hline $\begin{array}{l}\text { Low chord } \\
\text { elevation }\end{array}$ & - & - & - & - & - & - & - & - & - & - & - \\
\hline $\begin{array}{l}\text { Bed } \\
\text { elevation }\end{array}$ & - & - & - & - & - & - & - & - & - & - & - \\
\hline $\begin{array}{l}\text { Low chord } \\
\text { to bed }\end{array}$ & - & - & - & - & - & - & - & - & - & - & - \\
\hline
\end{tabular}

Source (FEMA, VTAOT, Other)? VTAOT

Comments: Downstream arch face channel cross section. *Point of contact where the steel arch meets the concrete footing.

\begin{tabular}{|l|l|l|l|l|l|l|l|l|l|l|l|}
\hline Station & -12.5 & -12.5 & +2.5 & +12.5 & +12.5 & - & - & - & - & - & - \\
\hline Feature & $\begin{array}{l}\text { footing } \\
\text { bottom }\end{array}$ & LCL* & - & $\mathbf{L C R} *$ & $\begin{array}{l}\text { footing } \\
\text { bottom }\end{array}$ & - & - & - & - & - & - \\
\hline $\begin{array}{l}\text { Low chord } \\
\text { elevation }\end{array}$ & & 476.2 & - & $\mathbf{4 7 6 . 2}$ & & - & - & - & - & - & - \\
\hline $\begin{array}{l}\text { Bed } \\
\text { elevation }\end{array}$ & 471.5 & 475.7 & 475.6 & 475.5 & 471.5 & - & - & - & - & - & - \\
\hline $\begin{array}{l}\text { Low chord } \\
\text { to bed }\end{array}$ & - & - & - & - & - & - & - & - & - & - & - \\
\hline Station & - & - & - & - & - & - & - & - & - & - & - \\
\hline Feature & - & - & - & - & - & - & - & - & - & - & - \\
\hline $\begin{array}{l}\text { Low chord } \\
\text { elevation }\end{array}$ & - & - & - & - & - & - & - & - & - & - & - \\
\hline $\begin{array}{l}\text { Bed } \\
\text { elevation }\end{array}$ & - & - & - & - & - & - & - & - & - & - & - \\
\hline $\begin{array}{l}\text { Low chord } \\
\text { to bed }\end{array}$ & - & - & - & - & - & - & - & - & - & - & - \\
\hline
\end{tabular}




\section{APPENDIX E: \\ LEVEL I DATA FORM}


U. S. Geological Survey

Bridge Field Data Collection and Processing Form

Qa/Qc Check by: MS Date: 6 /26/97

\section{Structure Number}

READTH00510029

Computerized by: $\mathbf{M S}$ Date: $\underline{6} / \mathbf{2 6 / 9 7}$

Reviewd by:

RLB Date: $3 / 30 / 98$

\section{A. General Location Descriptive}

1. Data collected by (First Initial, Full last name) M. WEBER

2. Highway District Number 04

Date $(M M / D D / Y Y) \underline{3} / \underline{\mathbf{2 9}} / 1995$

County WINDSOR (027)

Mile marker $\mathbf{0 0 0 0 0 0}$

Waterway (I - 6) MILL BROOK

Town READING (58375)

Route Number TH051

Road Name AGONY HILL ROAD

Hydrologic Unit Code: $\mathbf{0 1 0 8 0 1 0 4}$

3. Descriptive comments:

This structure is a multi-plate arch culvert. It is located 0.06 miles from the junction with VT 106.

\section{B. Bridge Deck Observations}
4. Surface cover... LBUS 4
RBUS 4
LBDS 4
RBDS 6
Overall 4

(2b us, ds,lb,rb: 1- Urban; 2- Suburban; 3- Row crops; 4- Pasture; 5- Shrub- and brushland; 6- Forest; 7- Wetland)
5. Ambient water surface...US $\underline{2}$
UB 1
DS $\underline{2}$
(1- pool; 2- riffle)

6. Bridge structure type 7 (1- single span; 2- multiple span; 3- single arch; 4- multiple arch; 5-cylindrical culvert; 6- box culvert; or 7- other)

7. Bridge length 27 (feet)

Span length $\underline{\mathbf{2 5}}$ (feet)

Bridge width -(feet)

\section{Road approach to bridge:}
8. LB 1
RB 2
( 0 even, 1- lower, 2- higher)
9. LB
RB $\underline{2}$
(1- Paved, 2- Not paved)

10. Embankment slope (run / rise in feet / foot)

US left

US right

\begin{tabular}{|c|c|c|c|}
\hline \multicolumn{2}{|c|}{ Protection } & \multirow{2}{*}{ 13.Erosion } & 14.Severity \\
\hline 11.Type & 12.Cond. & - & $\underline{\mathbf{1}}$ \\
\hline $\mathbf{0}$ & - & $\mathbf{0}$ & $\mathbf{0}$ \\
\hline $\mathbf{0}$ & - & $\mathbf{0}$ & $\mathbf{0}$ \\
\hline $\mathbf{0}$ & - & $\mathbf{0}$ \\
\hline $\mathbf{0}$ & - & $\mathbf{0}$ & $\mathbf{0}$ \\
\hline
\end{tabular}

Bank protection types: 0- none; 1- < 12 inches;

2- < 36 inches; 3- < 48 inches;

4- < 60 inches; 5- wall / artificial levee

Bank protection conditions: 1- good; 2- slumped;

3- eroded; 4- failed

Erosion: 0 - none; 1- channel erosion; 2-

road wash; 3- both; 4- other

Erosion Severity: 0 - none; 1- slight; 2- moderate;

\section{Channel approach to bridge (BF):}

15. Angle of approach: $\mathbf{1 5}$

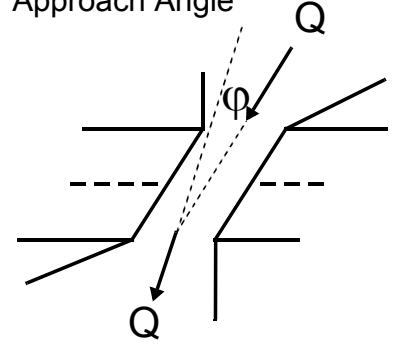

17. Channel impact zone 1 :

Where? LB $(L B, R B)$

Range? 5 feet US

Channel impact zone 2:

Where? RB (LB, RB)

Range? 75 feet $\underline{\text { DS }}$

Impact Severity: 0- none to very slight; 1- Slight; 2- Moderate; 3- Severe
16. Bridge skew: $\mathbf{3 0}$ Bridge Skew Angle

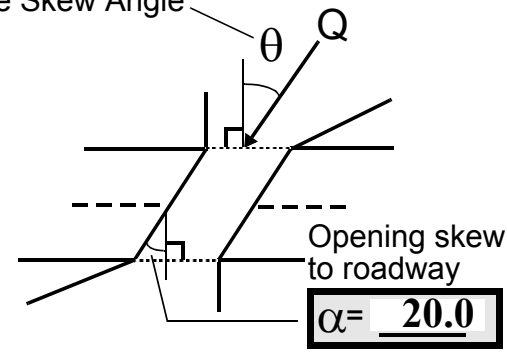

\section{Exist? $\mathbf{Y}(\mathrm{Y}$ or $N)$}

Severity 2

(US, UB, DS) to $\underline{\mathbf{5 0}}$ feet $\underline{\mathbf{U S}}$

Exist? Y $(Y$ or $N)$

Severity 3

, UB, DS) to 100 feet $\underline{\mathbf{D S}}$ 
18. Bridge Type: 2

1a- Vertical abutments with wingwalls

1 b- Vertical abutments without wingwalls

2- Vertical abutments and wingwalls, sloping embankment Wingwalls parallel to abut. face

3- Spill through abutments

4- Sloping embankment, vertical wingwalls and abutments

Wingwall angle less than $90^{\circ}$.

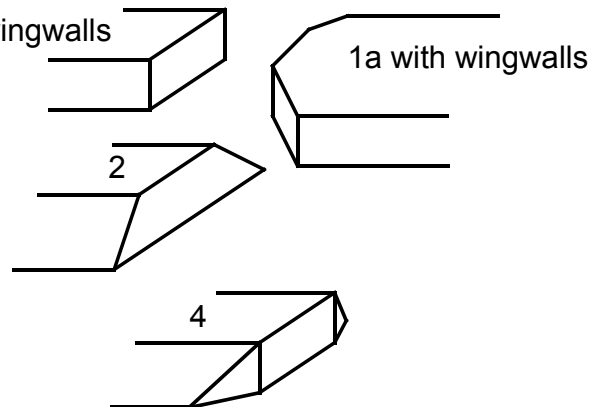

19. Bridge Deck Comments (surface cover variations, measured bridge and span lengths, bridge type variations,

approach overflow width, etc.)

4. The immediate banks US are shrub and brushland, with pasture on the overbanks. On the RBUS, there is a house about 150 feet from the culvert with some trees between the pasture and this house. The immediate banks DS have trees and the RBDS is forested with a house about 150 feet from the culvert.

6. The structure is described as a "multi-plate arch culvert" accoriding to the historical form.

7. The measured culvert width is $\mathbf{2 4}$ feet at the bottom; 27 feet including footing widths. The top length is $\mathbf{4 0 . 5}$ feet and the bottom length is 60.5 feet. The roadway width is 17.5 feet, of which 14 feet is dirt road and the rest is the narrow shoulders.

15 and 16. The ambient channel meanders. The approach and skew angles were taken using estimates of bank full flow immediately US and DS of the culvert. VTAOT lists no opening skew to roadway, but it was measured at 20 degrees.

17. The US impact is at the US left culvert corner. There is a cut bank here and some of the stones set on the US left side of the culvert have slumped.

\section{Upstream Channel Assessment}

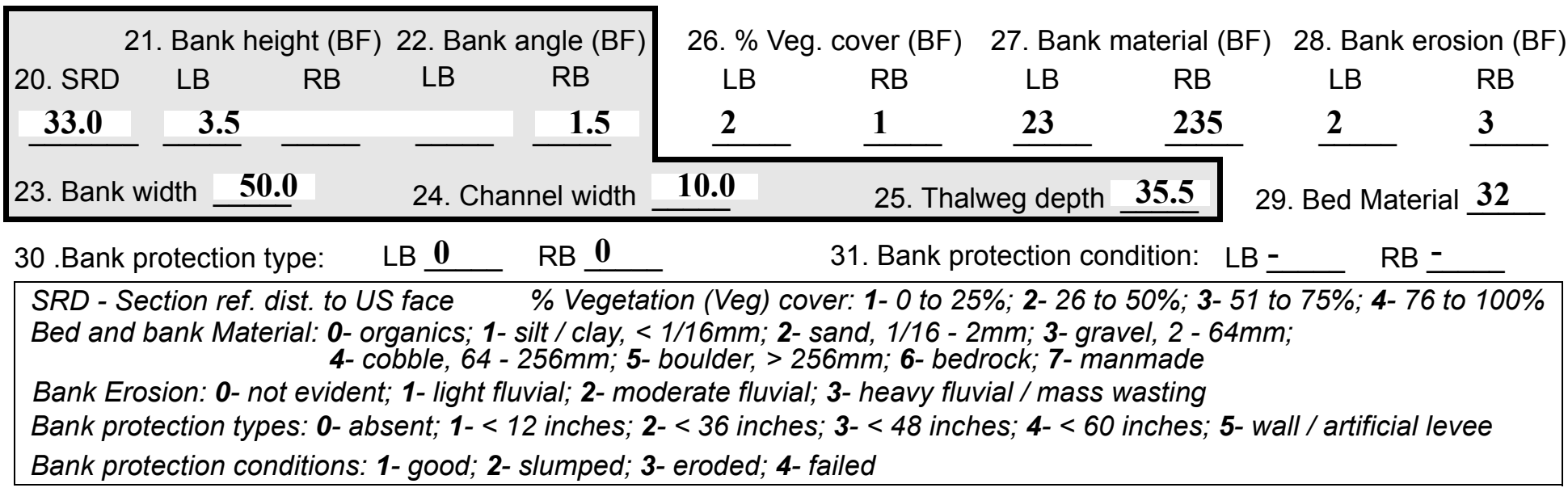

32. Comments (bank material variation, minor inflows, protection extent, etc.):

27. The bank material is sand and gravel with occasional boulders on the RB.

29. The bed material is gravel and sand.

All US distances are measured from the US culvert face, which is about 12 feet US from the US edge of the road and about 10 feet DS of the US right and left culvert ends. 
36. Point bar extent: $\mathbf{0}$ feet US

(US, UB) to $\mathbf{7 0}$ feet US

(US, UB, DS) positioned $\mathbf{8 0}$ \%LB to $100 \%$ RB

37. Material: $\mathbf{2}$

38. Point or side bar comments (Circle Point or Side; Note additional bars, material variation, status, etc.):

Point bar material is sand and gravel. Some shrubs are growing on the bar.

39. Is a cut-bank present? $\mathbf{Y}$ (Y or if $N$ type ctrl-n cb)

40. Where? LB (LB or RB)

41. Mid-bank distance: $\mathbf{5}$

42. Cut bank extent: 5

feet $\underline{\mathbf{U S}}$ (US, UB) to $\underline{\mathbf{5 0}}$ feet $\underline{\mathbf{U S}}$ (US, UB, DS)

43. Bank damage: 1

(1- eroded and/or creep; 2- slip failure; 3- block failure)

44. Cut bank comments (eg. additional cut banks, protection condition, etc.):

The greatest damage is up against the stone embankment on the left side of the culvert. Some stones have slumped.

\section{Is channel scour present? $\mathbf{N}$ ( $Y$ or if $N$ type ctrl-n cs)}

47. Scour dimensions: Length Width -

Depth :-

46. Mid-scour distance: -

48. Scour comments (eg. additional scour areas, local scouring process, etc.):

Local scour exists at the upstream end of the culvert. The upstream left culvert footing is threatened.

49. Are there major confluences? $\mathbf{N}$

51. Confluence 1: Distance Confluence 2: Distance 52. Enters on Enters on 54. Confluence comments (eg. confluence name):

NO MAJOR CONFLUENCES
50. How many? -

53. Type(1- perennial; 2- ephemeral)

Type (1-perennial; 2- ephemeral)

\section{Under Bridge Channel Assessment}

55. Channel restraint (BF)? LB 2

\begin{tabular}{|ccccc}
\hline \multicolumn{2}{|c}{ 56. Height (BF) } & \multicolumn{3}{c}{57 Angle (BF) } \\
LB & RB & LB & RB \\
$\mathbf{2 5 . 5}$ & & & $\mathbf{0 . 5}$ & \\
\hline
\end{tabular}
(1- natural bank; 2- abutment; 3- artificial levee)

58. Bank width (BF) -

59. Channel width -

61. Material (BF)

LB RB

$2 \quad 7$ (LB or $R B)$

Bed and bank Material:

62. Erosion (BF)

LB RB

7

63. Bed Material -

Bed and bank Material: 0- organics; 1 - silt / clay, < 1/16mm; 2- sand, 1/16
5- boulder, > 256mm; 6- bedrock; 7- manmade

Bank Erosion: 0- not evident; 1- light fluvial; 2- moderate fluvial; 3- heavy fluvial / mass wasting

64. Comments (bank material variation, minor inflows, protection extent, etc.):

3

The culvert is a corrugated, galvanized steel arch with stone fill around the arch perimeter, including the sides above the concrete footings.

63. The bed material is sand in the US scoured area and gravel and sand elsewhere. 
65. Debris and Ice Is there debris accumulation?

67. Debris Potential 1 (1- Low; 2- Moderate; 3- High)

69. Is there evidence of ice build-up? $\underline{2}(Y$ or $N)$

70. Debris and Ice Comments:

1

There is a large bank failure DS with trees lying in the stream. There are some small sticks at the US right culvert corner, but nothing substantial. The stream meanders in a wide floodplain and although the US reach is a riffle, the culvert is not in the uplands. Lateral movement could cause trees to fall into the stream. The culvert will block some of the bank full flow and the low sides may trap debris.

\begin{tabular}{|l|c|c|c|c|c|c|c|c|}
\hline Abutments & $\begin{array}{c}71 . \text { Attack } \\
\angle \text { (BF) }\end{array}$ & $\begin{array}{c}\text { 72. Slope } \angle \\
\text { (Qmax) }\end{array}$ & $\begin{array}{c}\text { 73. Toe } \\
\text { loc. (BF) }\end{array}$ & $\begin{array}{c}\text { 74. Scour } \\
\text { Condition }\end{array}$ & $\begin{array}{c}75 . \text { Scour } \\
\text { depth }\end{array}$ & $\begin{array}{c}\text { 76. Exposure } \\
\text { depth }\end{array}$ & 77. Material & 78. Length \\
\hline LABUT & & - & $\mathbf{5 0}$ & $\mathbf{2}$ & $\mathbf{2}$ & $\mathbf{3}$ & $\mathbf{4 . 5}$ & $\mathbf{9 0 . 0}$ \\
\hline RABUT & $\mathbf{3 / 1}$ & $\mathbf{1 5}$ & $\mathbf{5 0}$ & & & $\mathbf{2}$ & $\mathbf{2}$ & - \\
\hline
\end{tabular}

Pushed: $L B$ or RB

Toe Location (Loc.): 0- even, 1- set back, 2- protrudes

Scour cond.: 0- not evident; 1- evident (comment); 2- footing exposed; 3-undermined footing; 4- piling exposed; 5- settled; 6- failed

Materials: 1- Concrete; 2- Stone masonry or drywall; 3- steel or metal; 4- wood

79. Abutment comments (eg. undermined penetration, unusual scour processes, debris, etc.):

1

2

$3 / 1$

There is a scour hole at the US face; maximum scour is 3 feet deep (4 feet total water depth) at 5 feet US. The scour extends 15 feet US to 10 feet under the culvert and is a maximum of 13 feet wide at 0 feet US.

77. The material of the abutments (sides of the culvert) is corrugated, galvanized steel and concrete footings.

The thalweg moves from the scour hole at the US left culvert corner to follow the right culvert footing.

80. Wingwalls:

Exist? Material? Scour Scour Exposure Angle? Length? Condition? depth? depth?

USLWW:

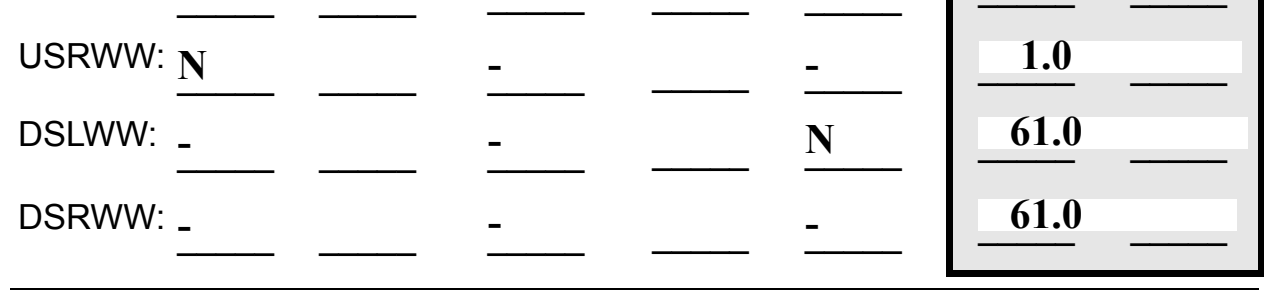

Wingwall materials: 1- Concrete; 2- Stone masonry or drywall; 3- steel or metal; 4- wood

82. Bank / Bridge Protection:

\begin{tabular}{|l|l|l|l|l|l|l|l|c|}
\hline Location & USLWW & USRWW & LABUT & RABUT & LB & RB & DSLWW & DSRWW \\
\hline Type & - & - & N & - & - & - & $\mathbf{2}$ & $\mathbf{1}$ \\
\hline Condition & N & - & - & - & - & - & $\mathbf{4}$ & $\mathbf{4}$ \\
\hline Extent & - & - & - & - & - & $\mathbf{2}$ & $\mathbf{2}$ & - \\
\hline
\end{tabular}

Bank / Bridge protection types: 0- absent; 1- < 12 inches; 2- < 36 inches; 3- < 48 inches; 4- < 60 inches; 
83. Wingwall and protection comments (eg. undermined penetration, unusual scour processes, etc.):

-
-
-
-
-
-
-
-
-
-

\section{Piers:}

84. Are there piers? Th (Y or if $N$ type ctrl-n pr)

\begin{tabular}{|l|l|l|l|l|l|l|l|}
\hline \multirow{2}{*}{$\begin{array}{l}85 . \\
\text { Pier no. }\end{array}$} & \multicolumn{3}{|c|}{ width (w) feet } & \multicolumn{3}{c|}{ elevation (e) feet } \\
\cline { 2 - 9 } & w1 & w2 & w3 & e@w1 & e@w2 & e@w3 \\
\hline Pier 1 & - & - & - & - & - & - \\
\hline Pier 2 & - & - & - & - & - & - \\
\hline Pier 3 & - & - & - & - & - & - \\
\hline Pier 4 & - & - & - & - & - & - \\
\hline
\end{tabular}

\begin{tabular}{|l|l|l|l|l|}
\hline Level 1 Pier Descr. & \multicolumn{1}{|c|}{1} & \multicolumn{1}{|c|}{2} & \multicolumn{1}{|c|}{3} & \multicolumn{1}{|c|}{} \\
\hline 86. Location (BF) & ere is & the & fill is & the \\
\hline 87. Type & stone & cul- & not & cul- \\
\hline 88. Material & fillat & vert & in & vert \\
\hline 89. Shape & the & on & the & wher \\
\hline 90. Inclined? & upst & the & chan & e the \\
\hline 91. Attack $\angle$ (BF) & ream & left & nel, & cul- \\
\hline 92. Pushed & and & and & but & vert \\
\hline 93. Length (feet) & - & - & - & - \\
\hline 94. \# of piles & dow & right & is & meet \\
\hline 95. Cross-members & nstre & sides & piled & s the \\
\hline 96. Scour Condition & am & - & on & bank \\
\hline 97. Scour depth & ends & This & top & - In \\
\hline 98. Exposure depth & of & stone & of & addi- \\
\hline
\end{tabular}

LFP, LTB, LB, MCL, MCM, MCR, RB, RTB, RFP

1- Solid pier, 2- column, 3- bent

1-Wood; 2-concrete; 3- metal; 4- stone

1- Round; 2- Square; 3- Pointed

Y-yes; $N-$ no

$L B$ or $R B$

0- none; 1- laterals; 2- diagonals; 3- both

0- not evident; 1- evident (comment);

2- footing exposed; 3- piling exposed;

4- undermined footing; 5- settled; 6- failed 
99. Pier comments (eg. undermined penetration, protection and protection extent, unusual scour processes, etc.):

tion, there is some stone fill in the channel at the upstream left end of the culvert. The stone fill in that area has slumped from channel erosion.

$\mathbf{N}$

100.

\section{E. Downstream Channel Assessment}

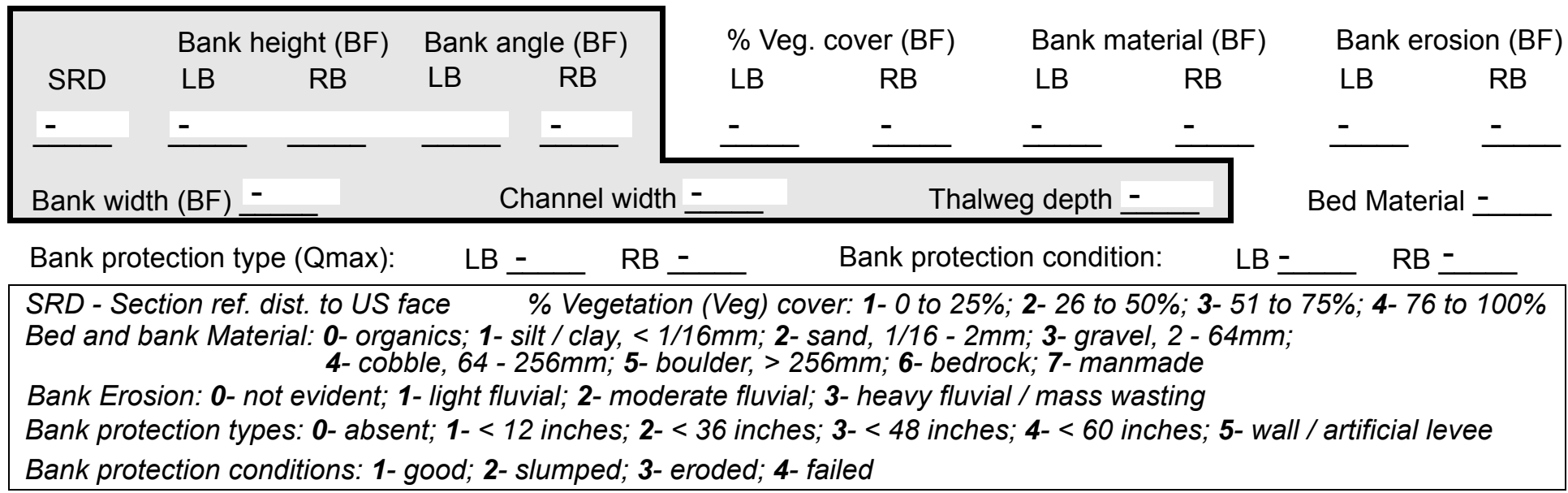

Comments (eg. bank material variation, minor inflows, protection extent, etc.):

$-$

$-$

-

-

-

-

$-$

-

-

-

-

-

-

-

101. Is a drop structure present? _ ( $Y$ or $N$, if $N$ type ctrl-n ds) 102. Distance: ___ feet
103. Drop: - feet
104. Structure material: -
(1- steel sheet pile; 2- wood pile; 3- concrete; 4- other)

105. Drop structure comments (eg. downstream scour depth):

-

-

-

- 
106. Point/Side bar present? (Y or $N$. if $N$ type ctrl-n pb)Mid-bar distance:

Mid-bar width: -

Point bar extent: feet -

(US, UB, DS) to feet (US, UB, DS) positioned $\%$ LB to $\% \mathrm{RB}$ Material:

Point or side bar comments (Circle Point or Side; note additional bars, material variation, status, etc.):

S a cut-bank present? $\mathbf{N}$ (Y or if $N$ type ctrl-n cb) Where? $\underline{\mathbf{O}}$ (LB or RB) Mid-bank distance: PIE Cut bank extent: $\underline{\mathbf{R S}}$ feet ___ (US, UB, DS) to feet (US, UB, DS)

Bank damage: (1- eroded and/or creep; 2- slip failure; 3- block failure)

Cut bank comments (eg. additional cut banks, protection condition, etc.):

Is channel scour present? Scour dimensions: Length $\underline{4}$ Width 1 (Y or if $N$ type ctrl-n cs)

Mid-scour distance: $\underline{\mathbf{3}}$

3 Scour comments (eg. additional scour areas, local scouring process, etc.):

3

0

0

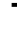

Are there major confluences? ___ (Y or if $N$ type ctrl-n $m c)$

Confluence 1: Distance $\mathbf{e}$ is Enters on mas (LB or RB)

Enters on ing ( $L B$ or $R B)$

Positioned $\mathbf{3}$ \%LB to $\underline{3}$ $\% \mathrm{RB}$
Depth: 1 
108. Evolution comments (Channel evolution not considering bridge effects; See HEC-20, Figure 1 for geomorphic descriptors):

$h$ gravel is exposed. Downstream measurements are made from the DS face of the culvert, which is 12 feet DS of the DS edge of the road and 10 feet US of the DS culvert corners. 


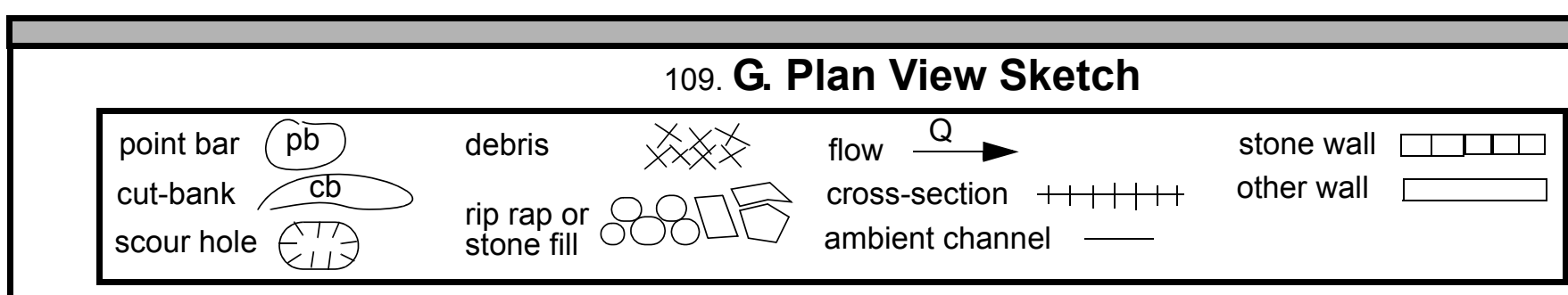


APPENDIX F:

SCOUR COMPUTATIONS 


\begin{tabular}{|c|c|c|c|}
\hline $\begin{array}{ll}\text { Structure Number: READTH00510029 } \\
\text { Road Number: } & \text { TH } 51\end{array}$ & & $\begin{array}{l}\text { Town : } \\
\text { County: }\end{array}$ & $\begin{array}{l}\text { READING } \\
\text { WINDSOR }\end{array}$ \\
\hline Stream: MILL BROOK & & & \\
\hline Initials RLB & Checked: & $\mathrm{EMB}$ & \\
\hline nalysis of contraction scour, liv & -bed or $\mathrm{cl}$ & lear wat & \\
\hline $\begin{array}{l}\text { Critical Velocity of Bed Material } \\
\text { Vc }=11.21^{*} 1^{\wedge} 0.1667 * \mathrm{D} 50^{\wedge} 0.33 \text { with } \mathrm{S}\end{array}$ & converted & to Eng & sh units \\
\hline (Richardson and Davis, 1995, p. 28 & eq. 16$)$ & & \\
\hline pproach section & & & \\
\hline Characteristic & $100 \mathrm{yr}$ & $500 \mathrm{yr}$ & other $Q$ \\
\hline Total discharge, cfs & 2500 & 3580 & 1000 \\
\hline Main Channel Area, ft2 & 338 & 362 & 273 \\
\hline Left overbank area, ft2 & 891 & 1098 & 365 \\
\hline Right overbank area, ft2 & 248 & 284 & 158 \\
\hline Top width main channel, ft & 36 & 36 & 36 \\
\hline Top width L overbank, ft & 304 & 304 & 239 \\
\hline Top width $\mathrm{R}$ overbank, ft & 52 & 54 & 46 \\
\hline D50 of channel, ft & 0.2544 & 0.2544 & 0.2544 \\
\hline D50 left overbank, ft & -- & -- & -- \\
\hline D50 right overbank, ft & -- & -- & -- \\
\hline $\mathrm{y} 1$, average depth, $\mathrm{MC}$, ft & 9.4 & 10.1 & 7.6 \\
\hline Y1, average depth, LOB, ft & 2.9 & 3.6 & 1.5 \\
\hline $\mathrm{y}^{1}$, average depth, $\mathrm{ROB}$, ft & 4.8 & 5.3 & 3.4 \\
\hline Total conveyance, approach & 116818 & 150820 & 51720 \\
\hline Conveyance, main channel & 35820 & 40213 & 25088 \\
\hline Conveyance, LOB & 60294 & 85240 & 16029 \\
\hline Conveyance, ROB & 20704 & 25367 & 10603 \\
\hline Percent discrepancy, conveyance & 0.0000 & 0.0000 & 0.0000 \\
\hline Qm, discharge, $\mathrm{MC}$, cfs & 766.6 & 954.5 & 485.1 \\
\hline Q1, discharge, LOB, cfs & 1290.3 & 2023.3 & 309.9 \\
\hline Qr, discharge, ROB, cfs & 443.1 & 602.1 & 205.0 \\
\hline $\mathrm{Vm}$, mean velocity $\mathrm{MC}, \mathrm{ft} / \mathrm{s}$ & 2.3 & 2.6 & 1.8 \\
\hline $\mathrm{Vl}$, mean velocity, LOB, ft/s & 1.4 & 1.8 & 0.8 \\
\hline Vr, mean velocity, ROB, ft/s & 1.8 & 2.1 & 1.3 \\
\hline Vc-m, crit. velocity, $M C$, ft/s & 10.3 & 10.4 & 10.0 \\
\hline Vc-1, crit. velocity, LOB, ft/s & ERR & ERR & ERR \\
\hline Vc-r, crit. velocity, ROB, ft/s & ERR & $\mathrm{ERR}$ & $\mathrm{ERR}$ \\
\hline Results & & & \\
\hline Live-bed(1) or Clear-Water(0) Cont & action $\mathrm{Scc}$ & our? & \\
\hline Main Channel & 0 & 0 & 0 \\
\hline Left Overbank & $\mathrm{N} / \mathrm{A}$ & $\mathrm{N} / \mathrm{A}$ & $\mathrm{N} / \mathrm{A}$ \\
\hline Right Overbank & $\mathrm{N} / \mathrm{A}$ & $\mathrm{N} / \mathrm{A}$ & $\mathrm{N} / \mathrm{A}$ \\
\hline
\end{tabular}


Clear water Contraction Scour in MAIN CHANNEL

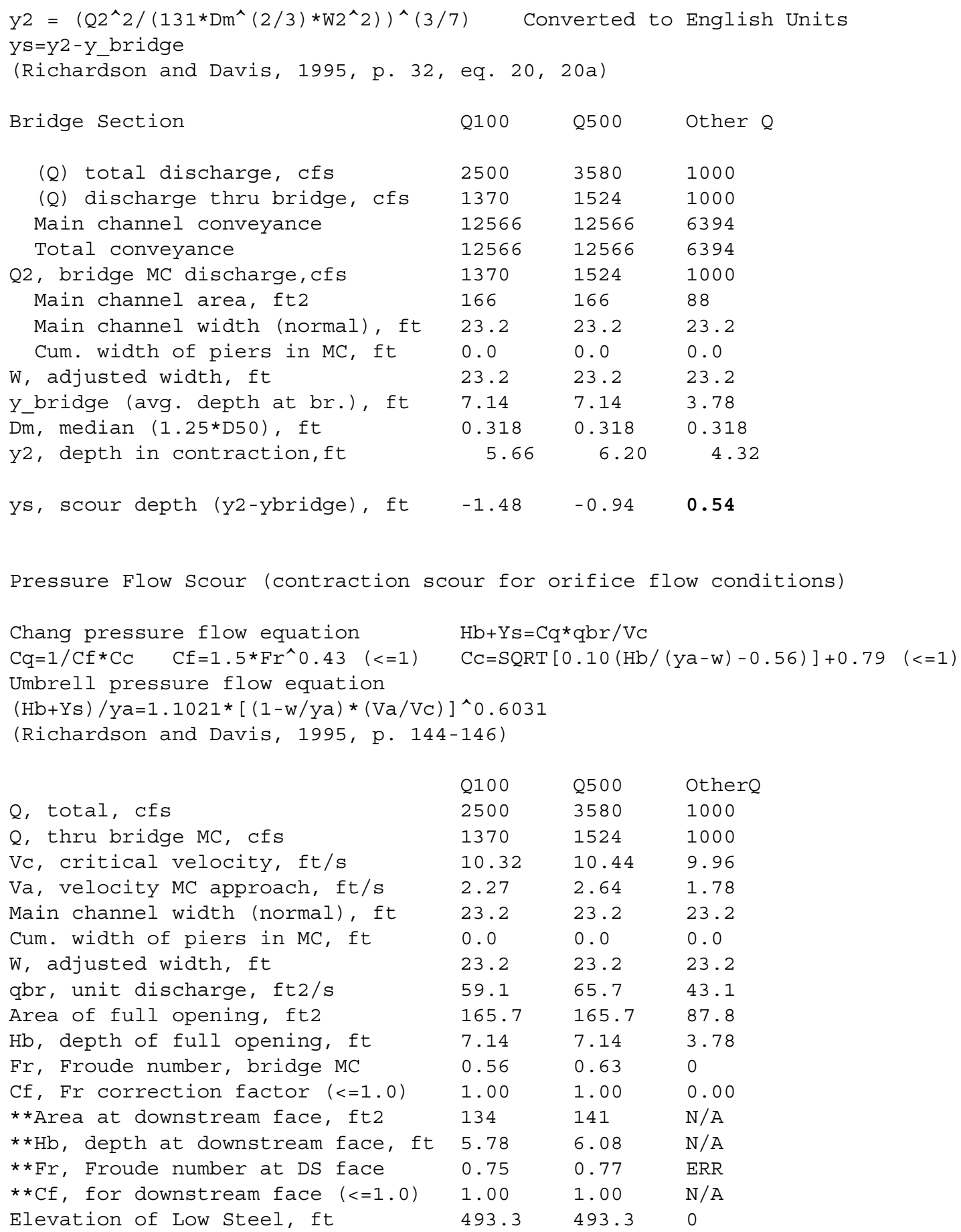




$\begin{array}{llll}\text { Elevation of Bed, ft } & 486.16 & 486.16 & -3.78 \\ \text { Elevation of Approach, ft } & 495 & 495.68 & 0 \\ \text { Friction loss, approach, ft } & 0.08 & 0.11 & 0 \\ \text { Elevation of WS immediately US, ft } & 494.92 & 495.57 & 0.00 \\ \text { Ya, depth immediately US, ft } & 8.76 & 9.41 & 3.78 \\ \text { Mean elevation of deck, ft } & 500.91 & 500.91 & 0 \\ \text { w, depth of overflow, ft ( > = ) } & 0.00 & 0.00 & 0.00 \\ \text { CC, vert contrac correction (<=1.0) } & 0.95 & 0.93 & 1.00 \\ \star \star C c, \text { for downstream face (<=1.0) } & 0.889587 & 0.88258 & \text { ERR } \\ \text { Ys, scour w/Chang equation, ft } & -1.12 & -0.38 & \mathrm{~N} / \mathrm{A} \\ \text { Ys, scour w/Umbrell equation, ft } & -3.27 & -2.62 & \mathrm{~N} / \mathrm{A}\end{array}$

**=for UNsubmerged orifice flow using estimated downstream bridge face properties.

**Ys, scour w/Chang equation, ft $0.66 \quad 1.05 \quad \mathrm{~N} / \mathrm{A}$

**Ys, scour w/Umbrell equation, ft $-1.90-1.55$ ERR

In UNsubmerged orifice flow, an adjusted scour depth using the Laursen equation results and the estimated downstream bridge face properties can also be computed (ys=y2-ybridgeDs)

$\begin{array}{llll}\text { Y2, from Laursen's equation, ft } & 5.66 & 6.20 & 4.32 \\ \text { WSEL at downstream face, ft } & 490.92 & 491.37 & -- \\ \text { Depth at downstream face, ft } & 5.78 & 6.08 & \mathrm{~N} / \mathrm{A} \\ \text { depth of scour (Laursen), ft } & -0.11 & 0.13 & \mathrm{~N} / \mathrm{A}\end{array}$

Armoring

$\mathrm{DC}=\left[\left(1.94 * \mathrm{~V}^{\wedge} 2\right) /(5.75 * \log (12.27 * \mathrm{y} / \mathrm{D} 90))^{\wedge} 2\right] /[0.03 *(165-62.4)]$

Depth to Armoring $=3 *(1 / \mathrm{PC}-1)$

(Federal Highway Administration, 1993)

$\begin{array}{rlll}\text { Downstream bridge face property } & 100-\mathrm{yr} & 500-\mathrm{yr} & \text { Other Q } \\ \text { Q, discharge thru bridge MC, cfs } & 1370 & 1524 & 1000 \\ \text { Main channel area (DS), ft2 } & 134 & 141 & 87.8 \\ \text { Main channel width (normal), ft } & 23.2 & 23.2 & 23.2 \\ \text { Cum. width of piers, ft } & 0.0 & 0.0 & 0.0 \\ \text { Adj. main channel width, ft } & 23.2 & 23.2 & 23.2 \\ \text { D90, ft } & 0.5081 & 0.5081 & 0.5081 \\ \text { D95, ft } & 0.5645 & 0.5645 & 0.5645 \\ \text { DC, critical grain size, ft } & 0.4333 & 0.4744 & 0.6431 \\ \text { PC, Decimal percent coarser than Dc } 0.176 & 0.133 & 0.026 \\ \text { Depth to armoring, ft } & & & \end{array}$

Abutment Scour

Froehlich's Abutment Scour

$\mathrm{Ys} / \mathrm{Y} 1=2.27 * \mathrm{~K} 1 * \mathrm{~K} 2 *\left(\mathrm{a}^{\prime} / \mathrm{Y} 1\right)^{\wedge} 0.43 * \mathrm{Fr} 1^{\wedge} 0.61+1$

(Richardson and Davis, 1995, p. 48, eq. 28)

\begin{tabular}{|c|c|c|c|c|c|c|}
\hline \multirow[b]{2}{*}{ Characteristic } & \multicolumn{2}{|c|}{ Left Abutment } & \multicolumn{4}{|c|}{ Right Abutment } \\
\hline & $100 \mathrm{yr}$ & $00 \mathrm{yr}$ & ther & $00 \mathrm{yr}$ & $0 \mathrm{yr}$ & her $Q$ \\
\hline (Qt), total discharge, cfs & 2500 & 3580 & 1000 & 2500 & 3580 & 1000 \\
\hline a', abut.length blocking flow, ft & 234.8 & 234.8 & 240 & 63.9 & 65.6 & 57.7 \\
\hline
\end{tabular}




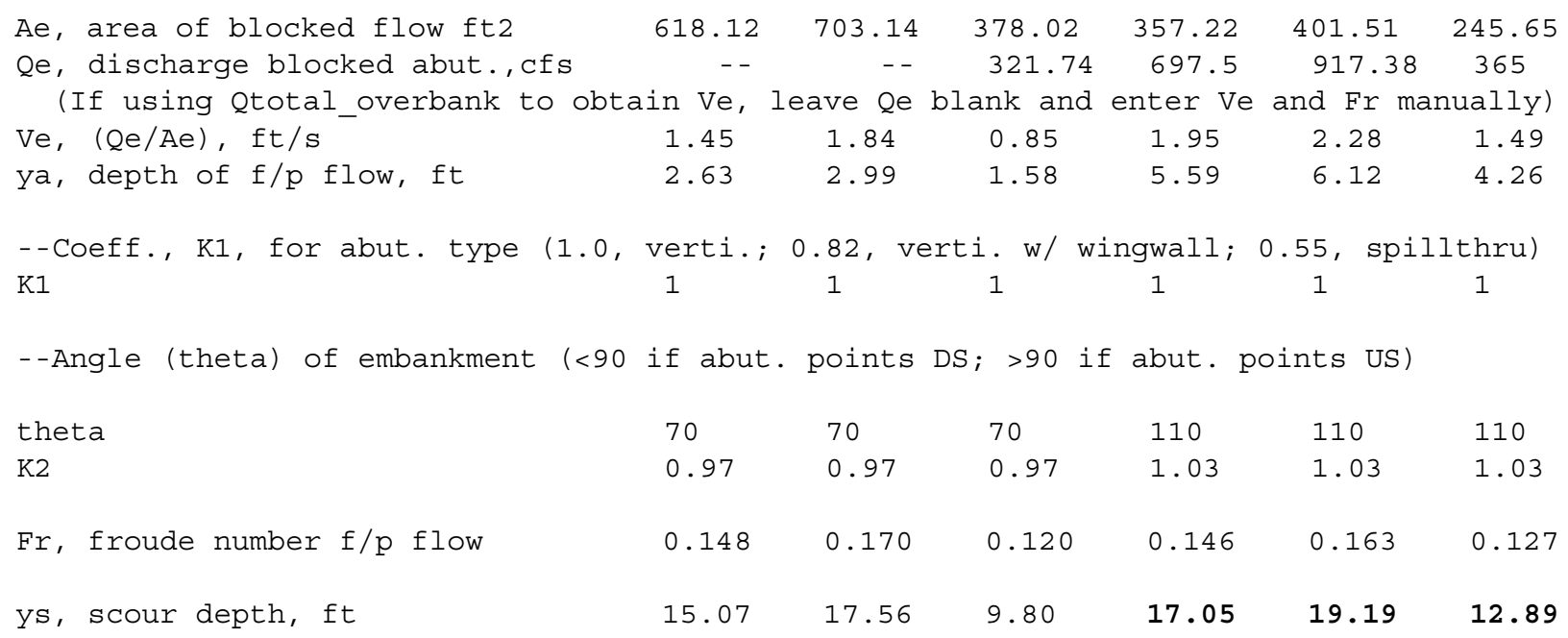

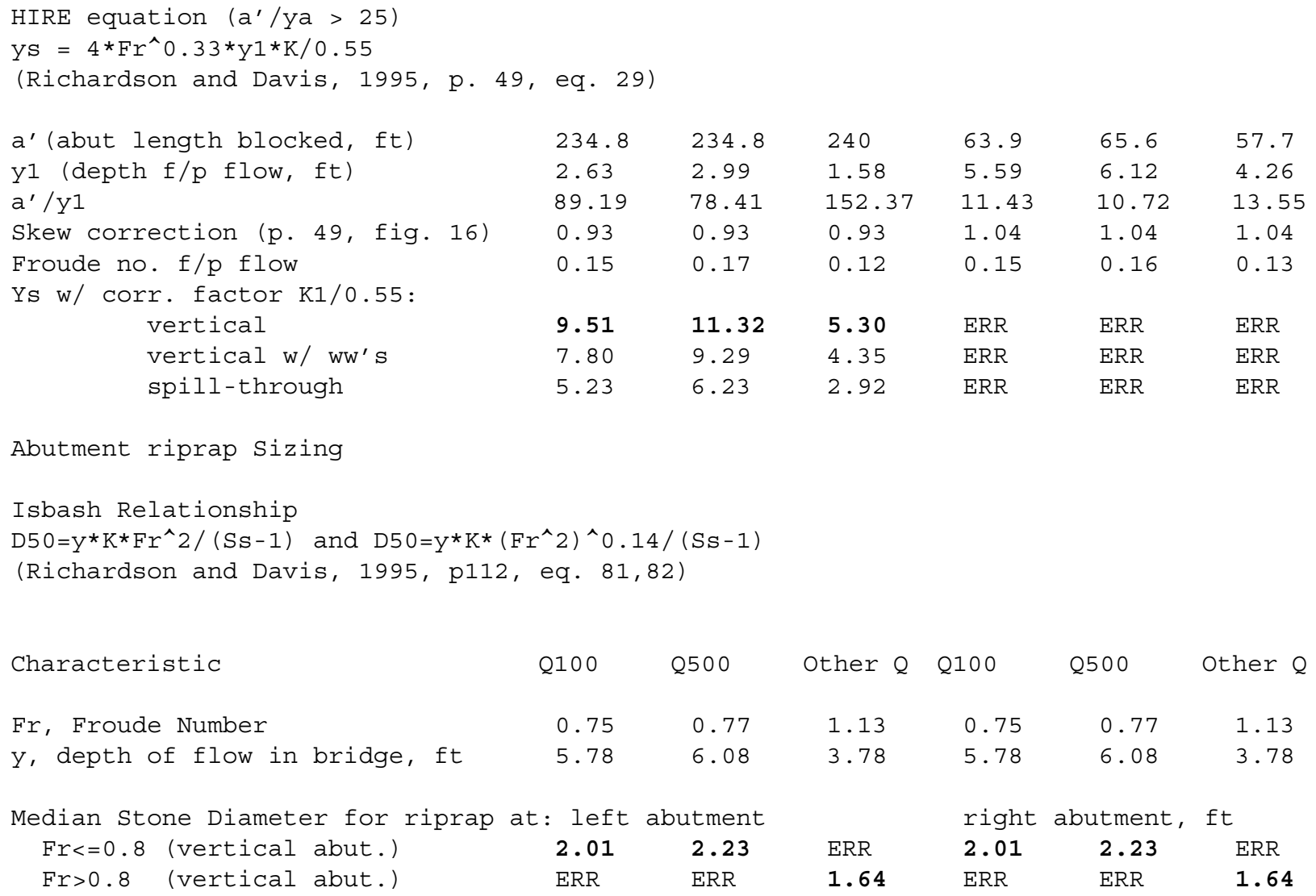


